\title{
Exploiting simultaneous observational constraints on mass and absorption to estimate the global direct radiative forcing of black carbon and brown carbon
}

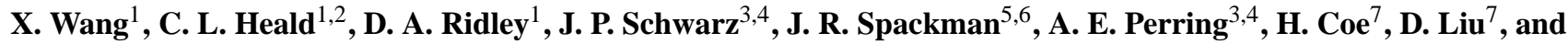 \\ A. D. Clarke ${ }^{8}$ \\ ${ }^{1}$ Department of Civil and Environmental Engineering, Massachusetts Institute of Technology, Cambridge, MA, USA \\ ${ }^{2}$ Department of Earth, Atmospheric and Planetary Sciences, Massachusetts Institute of Technology, Cambridge, MA, USA \\ ${ }^{3}$ Chemical Sciences Division, Earth System Research Laboratory, National Oceanic and Atmospheric Administration, \\ Boulder, Colorado, USA \\ ${ }^{4}$ Cooperative Institute for Research in Environmental Sciences, University of Colorado Boulder, Boulder, Colorado, USA \\ ${ }^{5}$ Physical Sciences Division, Earth System Research Laboratory, National Oceanic and Atmospheric Administration, Boulder, \\ Colorado, USA \\ ${ }^{6}$ Science and Technology Corporation, Boulder, Colorado, USA \\ ${ }^{7}$ Centre for Atmospheric Science, University of Manchester, Manchester, UK \\ ${ }^{8}$ Department of Oceanography, University of Hawaii, Honolulu, HI, USA
}

Correspondence to: X. Wang (xuanw12@mit.edu)

Received: 19 May 2014 - Published in Atmos. Chem. Phys. Discuss.: 30 June 2014

Revised: 10 September 2014 - Accepted: 12 September 2014 - Published: 20 October 2014

\begin{abstract}
Atmospheric black carbon (BC) is a leading climate warming agent, yet uncertainties on the global direct radiative forcing (DRF) remain large. Here we expand a global model simulation (GEOS-Chem) of BC to include the absorption enhancement associated with BC coating and separately treat both the aging and physical properties of fossil-fuel and biomass-burning BC. In addition we develop a global simulation of brown carbon $(\mathrm{BrC})$ from both secondary (aromatic) and primary (biomass burning and biofuel) sources. The global mean lifetime of BC in this simulation (4.4 days) is substantially lower compared to the AeroCom I model means (7.3 days), and as a result, this model captures both the mass concentrations measured in nearsource airborne field campaigns (ARCTAS, EUCAARI) and surface sites within $30 \%$, and in remote regions (HIPPO) within a factor of 2 . We show that the new BC optical properties together with the inclusion of $\mathrm{BrC}$ reduces the model bias in absorption aerosol optical depth (AAOD) at multiple wavelengths by more than $50 \%$ at AERONET sites worldwide. However our improved model still underestimates AAOD by a factor of 1.4 to 2.8 regionally, with the largest underestimates in regions influenced by fire. Us-
\end{abstract}

ing the RRTMG model integrated with GEOS-Chem we estimate that the all-sky top-of-atmosphere DRF of BC is $+0.13 \mathrm{Wm}^{-2}\left(0.08 \mathrm{Wm}^{-2}\right.$ from anthropogenic sources and $0.05 \mathrm{Wm}^{-2}$ from biomass burning). If we scale our model to match AERONET AAOD observations we estimate the DRF of $\mathrm{BC}$ is $+0.21 \mathrm{Wm}^{-2}$, with an additional $+0.11 \mathrm{Wm}^{-2}$ of warming from $\mathrm{BrC}$. Uncertainties in size, optical properties, observations, and emissions suggest an overall uncertainty in BC DRF of $-80 \% /+140 \%$. Our estimates are at the lower end of the $0.2-1.0 \mathrm{Wm}^{-2}$ range from previous studies, and substantially less than the $+0.6 \mathrm{Wm}^{-2}$ DRF estimated in the IPCC 5th Assessment Report. We suggest that the DRF of $\mathrm{BC}$ has previously been overestimated due to the overestimation of the $\mathrm{BC}$ lifetime (including the effect on the vertical profile) and the incorrect attribution of $\mathrm{BrC}$ absorption to BC. 


\section{Introduction}

Black carbon aerosol (BC), which is produced from incomplete combustion, is an important component of atmospheric particulate matter (PM). BC is strongly light-absorbing, and therefore plays a role similar to greenhouse gases as a climate warming agent and can influence cloud cover and emissivity and affect the atmosphere indirectly by changing the concentrations of liquid cloud droplets and ice nuclei (IPCC, 2013; Bond et al., 2013). Furthermore, BC deposited on ice and snow can reduce the surface albedo and accelerate melting (IPCC, 2013; Ramanathan and Carmichael, 2008; Flanner et al., 2007). In addition to climatic effects, BC adversely affects human health through direct inhalation of the particles which can include adsorbed harmful volatile organic compounds (VOCs) such as polycyclic aromatic hydrocarbons (PAHS) (Dachs and Eisenreich, 2000). Because of its adverse effects on both human health and climate, reducing $\mathrm{BC}$ is viewed as a policy strategy with potential co-benefits (Anenberg et al., 2012; Smith and Haigler, 2008).

The IPCC 5th Assessment Report (AR5) suggests that the direct radiative forcing (DRF) of atmospheric BC $\left(+0.6 \mathrm{Wm}^{-2}\right.$, with $+0.4 \mathrm{Wm}^{-2}$ of this from fossil and biofuels) is second only to $\mathrm{CO}_{2}$ (IPCC, 2013), further bolstering the concept of $\mathrm{BC}$ control as an effective climate mitigation strategy. The AR5 estimate is based on two studies: the multimodel assessment from AeroCom II (Aerosol Comparisons between Observations and Models) by Myhre et al. (2013) $\left(+0.23 \mathrm{Wm}^{-2}\right.$ from fossil and biofuel emissions), and the substantially higher forcing estimate of the Bond et al. (2013) assessment, which incorporates an observationally weighted scaling of previous modeling estimates $\left(+0.51 \mathrm{Wm}^{-2}\right.$ from fossil and biofuel emissions, $+0.2 \mathrm{Wm}^{-2}$ from biomass burning). This difference of more than a factor of 2 highlights both the uncertainty in BC DRF and the potential for a substantial underestimation of $\mathrm{BC}$ absorption in the current generation of global models. At the same time, previous studies suggest that AeroCom I models overestimate remote and high-altitude BC concentrations (Schwarz et al., 2008b; Koch et al., 2009) and that a shorter atmospheric BC lifetime ( $\sim 4$ days) than the typically simulated (5-10 days) is required to capture the low concentrations in the remote $\mathrm{Pa}$ cific (Wang et al., 2014). In this work we aim to reconcile these disparate observational constraints on BC.

Model estimates of BC DRF rely on an accurate representation of $\mathrm{BC}$ mass concentrations (dependent on emissions, aging, transport, and removal processes) as well as optical properties (dependent on mixing state, size, morphology, and refractive indices). The integrated effect of mass concentration and optical properties can be described by the aerosol optical depth (AOD), single scattering albedo (SSA), absorption aerosol optical depth (AAOD) and asymmetry factor, which are the basis for calculating DRF in models. These three factors are related by the following:
$\mathrm{AAOD}=\mathrm{AOD} \times(1-\mathrm{SSA})$.

Some studies have used observed BC concentrations to constrain model results before calculating DRF (Jacobson, 2001, 2012), however this approach neglects uncertainties in the optical properties of $\mathrm{BC}$. An alternative is to constrain a model by column AAOD, which generally represents the absorption of $\mathrm{BC}$ and can be retrieved from satellite and ground-based measurements by sun-photometer; however, both satellite and ground-based measurements suffer from significant uncertainties. The accuracy of ground-based sun-photometers (the observations used in the Bond et al., 2013 study) is limited under low aerosol loading, implying less reliable SSA retrievals under these conditions (Dubovik and King, 2000). The retrieved AAOD from satellite relies on predetermined aerosol models with a series of assumptions which are less accurate than ground-based measurements ( $\mathrm{Li}$ et al., 2009; Kahnert et al., 2010).

While AAOD observations may be essential to constraining the DRF of $\mathrm{BC}$, there remain additional challenges in interpreting these measurements. Observed column AAOD does not describe the vertical distribution of aerosol absorption. As a consequence, different vertical profiles and column loading of $\mathrm{BC}$ can produce the same estimate of column AAOD due to the inhomogeneous vertical distribution of solar flux and the positions of clouds (Zarzycki and Bond, 2010; Samset and Myhre, 2011), but may result in substantially different radiative effects. In addition, AAOD captures absorption from all aerosols, including dust and organic aerosol (OA). While dust sources may be geographically isolated from black carbon sources, OA is typically co-emitted with BC. Most climate models treat OA as a scattering-only aerosol (Chung et al., 2012), but recent studies show that OA can absorb light (Arola et al., 2011; Lukács et al., 2007; Hecobian et al., 2010; Chakrabarty et al., 2010; Kirchstetter et al., 2004; Chen and Bond, 2010). This light-absorbing OA (so-called "brown carbon": $\mathrm{BrC}$ ) is found in both urban and biomass-burning regions and is most absorbing at UV wavelengths. Chung et al. (2012) analyze the wavelength dependence of observed AAOD and estimate that $\mathrm{BrC}$ globally contributes $20 \%$ of the total absorption at $550 \mathrm{~nm}$ from all carbonaceous aerosols (BC+OA). Feng et al. (2013) also suggest $\mathrm{BrC}$ can contribute up to $20 \%$ to the absorption of all aerosols except dust and natural aerosols, while Lin et al. (2014) estimate that $\mathrm{BrC}$ contributes 27 to $70 \%$ of $\mathrm{BC}$ absorption globally, when using an alternate set of optical properties.

In this study, we aim to develop a model simulation of BC (and $\mathrm{BrC}$ ) that simultaneously meets the observational constraints for both mass and AAOD, and in doing so, improves the estimate of the global DRF of BC and its uncertainties. 


\section{Model description}

\subsection{The standard GC-RT model}

In this study, we use the global chemical transport model GEOS-Chem (Bey et al., 2001) coupled with the radiative transfer model RRTMG (Iacono et al., 2008), a configuration known as GC-RT (Heald et al., 2014). GEOS-Chem is driven by assimilated meteorology from the Goddard Earth Observing System (GEOS) at the NASA Global Modeling and Assimilation Office. Our simulations for 2006 to 2011 use the GEOS-5 meteorology and v9-1-3 of GEOS-Chem with a horizontal resolution of $2^{\circ} \times 2.5^{\circ}$ and 47 vertical levels.

The standard simulation of $\mathrm{BC}$ in GEOS-Chem is described in Park et al. (2003). The model assumes $80 \%$ of emitted BC is hydrophobic and the other $20 \%$ is hydrophilic. We update the hydrophilic fraction of $\mathrm{BC}$ emitted from biomass burning to $70 \%$ based on field observations (Akagi et al., 2012; Lack et al., 2012; Shamjad et al., 2012; Schwarz et al., 2008b, also see Sect. 2.2). Hydrophobic BC is aged to hydrophilic $\mathrm{BC}$ with an e-folding time of 1.15 days (the aging lifetime, Chin et al., 2002; Cooke et al., 1999). The dry removal process is based on a standard resistance-in-series model dependent on the local surface type and meteorological conditions (Zhang, 2001) and wet removal mainly follows the scheme described by Liu et al. (2001), which includes both in-cloud rainout (only for hydrophilic BC) and below-cloud washout (for all BC) for both large scale and convective precipitation. We also adopt a series of updates implemented by Wang et al. (2011), which include updated size-dependent parameters for below-cloud scavenging rate (Feng, 2007), a correction for the fractional area distribution between in-cloud and below-cloud scavenging, and updated ice/snow scavenging for hydrophobic BC. The standard simulation of primary organic aerosols (POA) is the same as BC except that POA is emitted as $50 \%$ hydrophilic. We also update this number to $70 \%$ for biomass burning. The formation of secondary organic aerosol (SOA) is described using a 2product model scheme and includes biogenic hydrocarbons (Chung and Seinfeld, 2002; Henze and Seinfeld, 2006), and aromatics (Henze et al., 2008) as precursors. The model also includes schemes for fine and coarse sea salt aerosols (Jaeglé et al., 2011) and mineral dust in four size bins (Fairlie et al., 2007; Ridley et al., 2012).

Anthropogenic emissions (including fossil and biofuel sources) of both BC and POA follow the Bond et al. (2007) global inventory, with some regional modifications. In the US, seasonality from Park et al., 2003 is imposed; in Europe, the seasonality is based on the Monitoring Atmospheric Composition and Climate/CityZEN EU projects (MACCity) anthropogenic emissions of the year 2010 (Diehl et al., 2012). In East Asia, we scale up the emissions totals for $\mathrm{BC}$ and POA by 16 and $28 \%$ to match a newer inventory of Zhang et al. (2009) with related seasonality. Use of this inventory has been shown to reduce bias in BC simulations at a national scale (Kondo et al., 2011a; Wang et al., 2013). These updates increase global anthropogenic emissions of BC by $11 \%$ compared to Bond et al. (2007) (from 4.4 to $4.9 \mathrm{Tg} \mathrm{yr}^{-1}$ ) and emissions of POA by $17 \%$ (from 8.7 to $10.1 \mathrm{Tg} \mathrm{yr}^{-1}$ ). Carbonaceous aerosol sources from biomass burning follow the year-specific monthly mean GFED3 inventory (van der Werf et al., 2010), contributing 1.6 to $2.3 \mathrm{Tg} \mathrm{yr}^{-1}$ of BC and 13.5 to $21.4 \mathrm{Tg} \mathrm{yr}^{-1}$ of POA in 2000 to 2011. We use the 1750 emission inventory of Dentener et al. (2006) for preindustrial conditions, with no fossil-fuel emissions, biofuel emissions of BC and POA of 0.39 and $1.56 \mathrm{Tg} \mathrm{yr}^{-1}$ (about $20 \%$ of present), and biomass-burning emissions of BC and POA of 1.03 and $12.8 \mathrm{Tg} \mathrm{yr}^{-1}$ (about $50 \%$ of present).

RRTMG is a radiative transfer code that calculates both longwave and shortwave atmospheric fluxes (Lacis and Oinas, 1991). Within GEOS-Chem, RRTMG calculates instantaneous radiative fluxes including both the total flux and the flux difference associated with specific atmospheric species (ozone, methane, sulfate, nitrate, ammonium, BC, OA, sea salt or dust) every $3 \mathrm{~h}$. The optical properties (AOD, SSA, and asymmetry parameter) of these species are calculated within GEOS-Chem. In the standard GC-RT, we assume that aerosols are externally mixed with log-normal size distributions based on the aerosol information defined in the Global Aerosol Data Set (GADS) database (Kopke et al., 1997) with updates from Drury et al. (2010), and hygroscopic growth factors from Martin et al. (2003). Here we use the $\mathrm{BC}$ density and refractive index (RI) recommended by Bond and Bergstrom (2006), which are found to agree better with observations (Park et al., 2003; Stier et al., 2006; Kondo et al., 2011a). Properties for BC are shown in Table 1. Optical properties are calculated at 7 discrete relative humidities (RH) for each wavelength using Mie code (Mischenko et al., 1999). Further details on the implementation of RRTMG in GEOS-Chem can be found in Heald et al. (2014).

The model configuration described above is our "baseline" GC-RT configuration. This will be compared to our "best" and "most absorbing" simulations described further below. Table 1 summarizes the assumptions we use for "baseline" and "best" simulations.

\subsection{Updated aging mechanism for $\mathrm{BC}$}

Upon emission $\mathrm{BC}$ is typically unmixed and hydrophobic, however once in the atmosphere, $\mathrm{BC}$ can be coated by other materials through processes such as condensation and coagulation (Stier et al., 2006; Moteki et al., 2007; Adachi et al., 2010; Liu et al., 2013). Since most coating materials are soluble, aged $\mathrm{BC}$ is assumed to be hydrophilic and can therefore be removed via in-cloud rainout, implying a shorter atmospheric lifetime. In addition, this coating or internal mixing can enhance the absorption of solar radiation (Fuller et al., 1999; Schnaiter et al., 2005; Bond and Bergstrom, 2006); therefore the aging process is important 
Table 1. Summary of parameterizations for carbonaceous aerosols in the "baseline" and "best" configurations in GC-RT.

\begin{tabular}{|c|c|c|}
\hline & Baseline & Best \\
\hline Initial hydrophilic fraction & \multicolumn{2}{|c|}{$\begin{array}{l}\text { BC: } 20 \% \text { in fossil/biofuel, } 70 \% \text { in biomass burning } \\
\text { POA: } 50 \% \text { in fossil/biofuel, } 70 \% \text { in biomass burning }\end{array}$} \\
\hline $\mathrm{BC}$ aging & $\begin{array}{l}\text { fixed aging rate, e-folding } \\
\text { time }=1.15 \text { days }\end{array}$ & $\begin{array}{l}\text { fossil-BC: aging rate } k=a\left[\mathrm{SO}_{2}\right][\mathrm{OH}]+b \\
\text { biofuel/biomass } \mathrm{BC} \text { : fixed aging rate, e-folding time }=4 \mathrm{~h}\end{array}$ \\
\hline BC Refractive Index & \multicolumn{2}{|c|}{$1.95-0.79 i$ at $550 \mathrm{~nm}$, with wavelength dependence in GADS } \\
\hline BC density & $1.8 \mathrm{~g} \mathrm{~cm}^{-3}$ & \\
\hline $\mathrm{BC}$ size (log-normal distribution) & $\mathrm{GMD}^{*}=40 \mathrm{~nm}, \delta=1.6$ & $\begin{array}{l}\text { fossil-BC: } \mathrm{GMD}=60 \mathrm{~nm}, \delta=1.6 \\
\text { biofuel/biomass } \mathrm{BC}: \mathrm{GMD}=140 \mathrm{~nm}, \delta=1.4\end{array}$ \\
\hline BC mixing & externally mixed & $\begin{array}{l}\text { absorption enhancement from coating of } \mathrm{BC}: 1.1 \text { for fossil-BC; } \\
1.5 \text { for biofuel/biomass } \mathrm{BC} \text { (hydrophilic } \mathrm{BC} \text { only) }\end{array}$ \\
\hline Br-POA & not included & $50 \%$ of biofuel/biomass-burning-emitted POA \\
\hline Br-SOA & not included & aromatic SOA \\
\hline
\end{tabular}

for the radiative impact of $\mathrm{BC}$. The standard GC-RT assumes an aging lifetime of 1.15 days, equivalent to a constant aging rate of $\sim 10^{-5} \mathrm{~s}^{-1}$, with no absorption enhancement; however, the aging rate likely differs with coating conditions. Given that the coating material is related to co-emitted species, we separately track BC emitted by fossil and biofuel/biomass sources in our simulations.

In urban areas dominated by fossil fuel, BC is typically coated by sulfate (Moteki et al., 2007; Moffet and Prather, 2009; Friedman et al., 2009); thus we assume that the aging process for fossil-BC is driven by the coating of condensed sulfuric acid. As suggested by Koch et al. (2001) and Liu et al. (2011), we assume that the gas-phase sulfuric acid is generally produced by the oxidation of $\mathrm{SO}_{2}$ by the hydroxyl radical $(\mathrm{OH})$ and is immediately condensed on BC. As a result, the aging rate of $\mathrm{BC}$ can be assumed to be proportional to the concentration of gas-phase sulfuric acid, which is further proportional to the concentration of $\mathrm{SO}_{2}$ and $\mathrm{OH}$ (Seinfeld and Pandis, 2006):

$k=1 / \tau=\alpha\left[\mathrm{H}_{2} \mathrm{SO}_{4}(\mathrm{~g})\right]+b=a\left[\mathrm{SO}_{2}\right][\mathrm{OH}]+b$,

where $k$ and $\tau$ are the aging rate and e-folding time (Liu et al., 2011). The constant term (b) represents the contribution of aging conversion due to the coagulation and aggregation of BC with other soluble particles; this process is very slow. By assuming a coagulation e-folding time of 20 days, $b$ is estimated to be $5.8 \times 10^{-7} \mathrm{~s}^{-1}$, improving the seasonality of simulated BC in the Arctic (Liu et al., 2011). Here we apply the Liu et al. (2011) BC aging scheme with dynamic [OH] and $\left[\mathrm{SO}_{2}\right]$ (rather than with fixed $\mathrm{SO}_{2}$ concentrations as in their study). This is supported by the experimental studies of R. Zhang et al. (2008) and Khalizov et al. (2009), who find a good linear relationship between gas-phase $\mathrm{H}_{2} \mathrm{SO}_{4}$ ex- posure (with associated $\mathrm{SO}_{2}$ concentration and constant $\mathrm{OH}$ levels) and the mass fraction of the shell coating on $\mathrm{BC}$. We fix the constant $a$ to be $2 \times 10^{-22} \mathrm{~cm}^{6}$ molec $^{-2} \mathrm{~s}^{-1}$, resulting in a mean e-folding time close to 1.15 days for typical urban conditions with $\mathrm{OH}$ concentrations of $10^{6}$ molec $\mathrm{cm}^{-3}$ and $\mathrm{SO}_{2}$ concentrations of $5 \times 10^{10}$ molec cm ${ }^{-3}(\sim 2 \mathrm{ppb})$. Here we assume that the aging rate is based on the atmospheric $\left[\mathrm{SO}_{2}\right]$ and $[\mathrm{OH}]$ concentrations (which contribute to the formation of gas-phase sulfuric acid), but this aging rate is not directly related to the rate of $\mathrm{SO}_{2}$ oxidation. Nitrate and organics may also coat BC in urban areas; however, as sulfate is the most common coating material in observations (Moteki et al., 2007; Moffet and Prather, 2009), we only consider sulfate here.

The biofuel/biomass-BC is more likely to be rapidly mixed with co-emitted soluble organic compounds. In field studies, this process is observed to be very fast (Akagi et al.,2012; Lack et al., 2012; Shamjad et al., 2012; Schwarz et al.,2008b, Moteki et al., 2007; Moffet and Prather, 2009), usually within several hours. Based on the observed data in Akagi et al. 2012 for chaparral fires in California, a new e-folding time of $4 \mathrm{~h}$ is assumed for the aging of biofuel/biomass BC. In addition, nearly all field observations of biomass burning (Akagi et al., 2012; Lack et al., 2012; Shamjad et al., 2012) show that more than $70 \%$ of BC emitted from fires are thickly coated by soluble materials after $1 \mathrm{~h}$. We therefore increase the initial hydrophilic fraction of emitted BC from this source from 20 to $70 \%$.

These changes decrease the global mean atmospheric lifetime of BC (from 5.1 days in the standard model to 4.4 days) and also imply that this lifetime depends on local source type and pollution levels. These aging updates are used in our "best" simulation. The $70 \%$ hydrophilic assumption for 
biomass-burning-emitted $\mathrm{BC}$ is also included in the "baseline" simulation to highlight the influence of the description of the aging process when comparing these two.

\subsection{Updated BC properties for optical calculation}

The optical effects of aerosols can be quantified with aerosol optical depth (AOD) and absorption AOD (AAOD). Calculation of these quantities within the model is based on the mass extinction efficiency (MEE) and single scattering albedo (SSA) as well as the simulated mass concentrations. The MEE and SSA are derived from Mie code (Mishchenko et al., 1999) as a function of the refractive index (RI), density and size distribution of the particles.

The size distributions of all aerosols in our simulations are assumed to be log-normal, defined by two parameters: the geometric median diameter (GMD) and standard deviation $(\delta)$. In the standard GC-RT, GMD and $\delta$ are assumed to be 40 and 1.6, however these factors should vary substantially with emission source. Generally, observations show that fossil-BC emitted in urban areas have a smaller GMD and larger $\delta$ than those from biomass-burning sources (Dubovik et al., 2002; Schwarz et al., 2008b). Using the median values from a series of field studies (Akagi et al., 2012; Schwarz et al., 2008b; Lack et al., 2012; Dubovik et al., 2002; Shamjad et al., 2012; Moffet and Prather, 2009; Knox et al., 2009; Kondo et al., 2011b), GMD is fixed at $60 \mathrm{~nm}$ and $140 \mathrm{~nm}$ for fossil and biofuel/biomass $\mathrm{BC}$, respectively, and $\delta$ is specified to be 1.6 and 1.4 for these two kinds of sources. At $550 \mathrm{~nm}$, MEE and MAE (mass absorption efficiency, $=$ MEE $\times(1-$ SSA) are calculated to be 6.9 and $5.9 \mathrm{~m}^{2} \mathrm{~g}^{-1}$ in the standard GCRT. With our updates, MEE and MAE increase to 8.2 and $6.3 \mathrm{~m}^{2} \mathrm{~g}^{-1}$ for fossil $\mathrm{BC}$ and 9.6 and $6.3 \mathrm{~m}^{2} \mathrm{~g}^{-1}$ for biofuel/biomass BC. The MAE values at $550 \mathrm{~nm}$ are at the lower end of the range $6.3-8.7 \mathrm{~m}^{2} \mathrm{~g}^{-1}$ suggested by Clarke et al. (2004) and Bond and Bergstrom (2006), but close to some other studies (Akagi et al., 2012; Schnaiter et al., 2005; Lewis et al., 2009). We use these size distributions in our "best" simulations for fossil and biofuel/biomass BC, and discuss the sensitivity of our results to size in Sect. 5 .

Owing to the lensing effect, a coated BC particle with a non-absorbing shell will produce greater absorption than the BC core alone (Fuller et al., 1999; Jacobson, 2000). It is not possible to model this effect explicitly in the externally mixed bulk aerosol scheme of GEOS-Chem; therefore we use absorption enhancement ( $\mathrm{AE}=\mathrm{MAE}$ with coating/MAE without coating) to describe this influence from internal mixing. Although a core-shell model can be used to estimate this $\mathrm{AE}$ value, it relies on the challenging estimation of the relative location and thickness of the shell at various conditions. Laboratory studies show that the AE changes very little when the shell is thick enough (Bueno et al., 2011; Cross et al., 2010; Shiraiwa et al., 2010; Shamjad et al., 2012; Knox et al., 2009), all estimating a maximum AE value around 2. Bond et al. (2006) conducted a series of core-shell calculations and found that the AE is 1.9 for thickly coated BC. Even without coating, the interactions between small spherules in an aggregate state can enhance the absorption by $30 \%$. However, this $30 \%$ enhancement disappears when the aggregation includes coating by a non-absorbing shell. Based on the AE for aggregated BC (1.3) and coated aggregated BC (1.9), Bond et al. (2006) suggest an AE of 1.5. This value is also close to values estimated from several field studies of biomassburning outflow (Schwarz et al., 2008a, b; Lack et al., 2012; Moffet and Prather, 2009). However, recent studies also show that the $\mathrm{AE}$ in urban regions may be even smaller (Schwarz et al., 2008b; Cappa et al., 2012). Cappa et al. (2012) observed a very small AE (1.1) in two urban regions of California (Los Angeles and Sacramento) during the summer of 2010. It remains unclear why the absorption enhancement of $\mathrm{BC}$ was observed to be so low, it may be due to a thin shell or other uncertain effects. In our "best" simulation, we apply $\mathrm{AE}=1.1$ for fossil-BC and 1.5 for biofuel/biomass $\mathrm{BC}$ as scaling factors on our aged (hydrophilic) BC. After applying the AE from coating, we estimate the "best" MAE at $550 \mathrm{~nm}$ to be $7.0 \mathrm{~m}^{2} \mathrm{~g}^{-1}$ for fossil-fuel-emitted BC and $9.5 \mathrm{~m}^{2} \mathrm{~g}^{-1}$ for biofuel and biomass-burning-emitted $\mathrm{BC}$.

We perform an additional set of "most absorbing" simulations, where we maximize the absorption from BC. In this simulation, the absorption enhancement is set to 2 for both fossil-BC and biofuel/biomass BC. The updated aging mechanisms in Sect. 2.2 decrease BC mass and increase the aged$\mathrm{BC}$ fraction. The first effect decreases the absorption while the second one enhances the absorption. The overall impact from the aging will be to decrease the absorption for both fossil- and biofuel/biomassBC. As a result, we do not apply the new aging mechanisms in our "most absorbing" simulation.

\subsection{Treatment of brown carbon}

Brown carbon absorbs radiation, particularly at UV wavelengths and therefore should be considered separately from "white" OA when simulating aerosol absorption. In our simulations we separately track two sources of $\mathrm{BrC}$ : Br-POA (brown primary organic aerosols) and Br-SOA (brown second organic aerosols).

There are currently no global emissions estimates for $\mathrm{BrC}$. In field observations (Arola et al., 2011; Lukács et al., 2007; Hecobian et al., 2010) Br-POA seems to be most abundant in the regions dominated by biofuel combustion or biomass burning. A series of laboratory measurements also demonstrate absorption from biofuel/biomass-burning-emitted OA (Chakrabarty et al., 2010; Kirchstetter et al., 2004; Chen and Bond, 2010). However, there is little information about how much of the OA emitted from biofuel/biomass burning is likely to be Br-POA. Similar to the approach of Park et al. (2010), here we simply assume $50 \%$ of the POA from biofuel and $25 \%$ from biomass burning is Br-POA (a total of $8 \mathrm{Tg} \mathrm{yr}^{-1}$ of $\mathrm{BrC}$ ). These values are discussed in Sect. 5 
in light of comparison with observations. Experiments show that most of the light-absorbing SOA is associated with aromatic carbonyls (Jaoui et al., 2008; Desyaterik et al., 2013; Lambe et al., 2013). Therefore we assume that aromatic SOA is Br-SOA in our simulation. Aromatic SOA is $8 \%$ of the total SOA simulated in the model and represents a source of 3.2 $\mathrm{Tg} \mathrm{yr}^{-1} \mathrm{BrC}$.

The aerosol properties of $\mathrm{BrC}$ in our simulation are identical to OA from the GADS database, with the exception of the imaginary part of refractive index $(i)$, which describes the absorption of aerosol. Based on Mie theory, this imaginary part can be derived from the measured MAE using the following relationship:

$i=(\mathrm{MAE} \cdot \rho \cdot \lambda) / 4 \pi$.

The $\rho$ and $\lambda$ are the density of measured aerosol and the corresponding wavelength of MAE. Many studies have measured the absorption of BrC (Chen and Bond, 2010; Zhang et al., 2013; Liu et al., 2013; Yang et al., 2009; Kirchstetter et al., 2004; Barnard et al., 2008; Chakarbarty et al., 2010; Song et al., 2013; Saleh et al., 2013; Updyke et al., 2012; Nakayama et al., 2013), but the measured absorption differs significantly. Generally the absorption is estimated by either measuring the absorption from organics extracted in water/acetone/methanol or calculating the absorption of total aerosols minus BC. Since the second method depends on the assumed and uncertain optical properties of BC, it is likely less accurate than the extraction method. Typically more than $90 \%$ of the measured $\mathrm{BrC}$ is extractable in acetone/methanol, and $30-70 \%$ is extractable in water. Here we assume that the acetone/methanol-soluble $\mathrm{BrC}$ is about to equal to the total $\mathrm{BrC}$, the water-soluble part is $\mathrm{Br}-\mathrm{SOA}$, and the acetone/methanol-soluble minus the water-insoluble part is Br-POA. The absorption measured for the water-soluble organics is substantially less than the acetone/methanol soluble organics. As a result, we derive the imaginary refractive index for Br-POA from the measured absorption in acetone/methanol-extracted experiments and the imaginary refractive index for $\mathrm{Br}-\mathrm{SOA}$ from the water-extracted experiments. The calculated i from previous field and laboratory studies are shown in Fig. 1.

It is clear from Fig. 1 that the imaginary part of the refractive index, $i$, varies substantially between different studies. Typically estimates from field observations are larger than values from laboratory experiments. We choose several studies which include measurements at multiple wavelengths (Chen and Bond, 2010; Zhang et al., 2013; Liu et al., 2013) as references for calculating $i$ for our simulations. We average these selected values and fit a logarithmic curve over the shortwave range (shown in Fig. 1). Our fitted curve represents values near the upper end of all the measurements, thereby representing near-maximum absorption properties for BrC. These values for Br-POA and Br-SOA are applied in our "best" and "most absorbing" simulations. The refractive index of $\mathrm{BrC}$ is only updated at wavelengths lower than 600nm. At longer wavelengths, our estimated $i$ is very small $(<0.005)$ and similar to the original OA assumption in GADS. We estimate the MAE at $440 \mathrm{~nm}$ to be $1.0 \mathrm{~m}^{2} \mathrm{~g}^{-1}$ for Br-POA and $0.3 \mathrm{~m}^{2} \mathrm{~g}^{-1}$ for Br-SOA.

\section{Observations}

We use two types of observations to constrain the global distribution and radiative impacts of $\mathrm{BC}$ : mass concentrations of $\mathrm{BC}$ from a series of aircraft campaigns and surface observations and wavelength-dependent AAOD from ground-based AERONET sites.

\subsection{Aircraft and surface concentration measurements}

The HIPPO (HIAPER Pole-to-Pole Observations, Schwarz et al., 2013) airborne campaign surveyed large latitude and altitude ranges $\left(80^{\circ} \mathrm{N}\right.$ to $\left.67^{\circ} \mathrm{S}, 0.3-14 \mathrm{~km}\right)$ with five flight series transecting the Pacific in January 2009, November 2009, March-April 2010, June-July 2011 and AugustSeptember 2011. Black carbon mass concentrations were measured aboard the NSF/NCAR Gulfstream V research aircraft with a single particle soot photometer (SP2, Schwarz et al., 2008a). The detection range for refractory black carbon (rBC) mass corresponds to $90-550 \mathrm{~nm}$ volume equivalent diameter, assuming $1.8 \mathrm{~g} \mathrm{~cm}^{-3}$ density, with a total uncertainty in accumulation mode rBC mass mixing ratio of $\pm 30 \%$ (Schwarz et al., 2013). The flight tracks, which extend across the remote Pacific into the Arctic, are shown in Fig. 2.

Two additional aircraft campaigns are included in our analyses. They are EUCAARI (European Integrated Project on Aerosol Cloud Climate and Air Quality Interactions) around the coastal areas of the United Kingdom during April and September in 2008 (McMeeking et al., 2010) and ARCTAS (Arctic Research of the Composition of the Troposphere from Aircraft and Satellites) during April, June and July, 2008 (Jacob et al., 2010). As in HIPPO, BC in these two campaigns was measured using the SP2 instrument. The detection range for particle diameter used in ARCTAS is 80-860 and $70-460 \mathrm{~nm}$ in EUCAARI. The uncertainty is estimated to be 10 and $30 \%$ in ARCTAS and EUCAARI (McMeeking et al., 2010; Kondo et al., 2011b). These campaigns provide a near-source contrast to the constraints provided by the HIPPO measurements.

For comparison with airborne measurements, the model is sampled both temporally and spatially to match the flight tracks.

As the horizontal coverage of the above aircraft campaigns is limited, surface measurements in three source regions, China, the US and Europe, are also included for comparison. In China, we use rural measurements obtained with online filter-based optical methods (Aethalometer and COSMOS) from Wang et al. (2013) in 2010 and filter-based thermal 

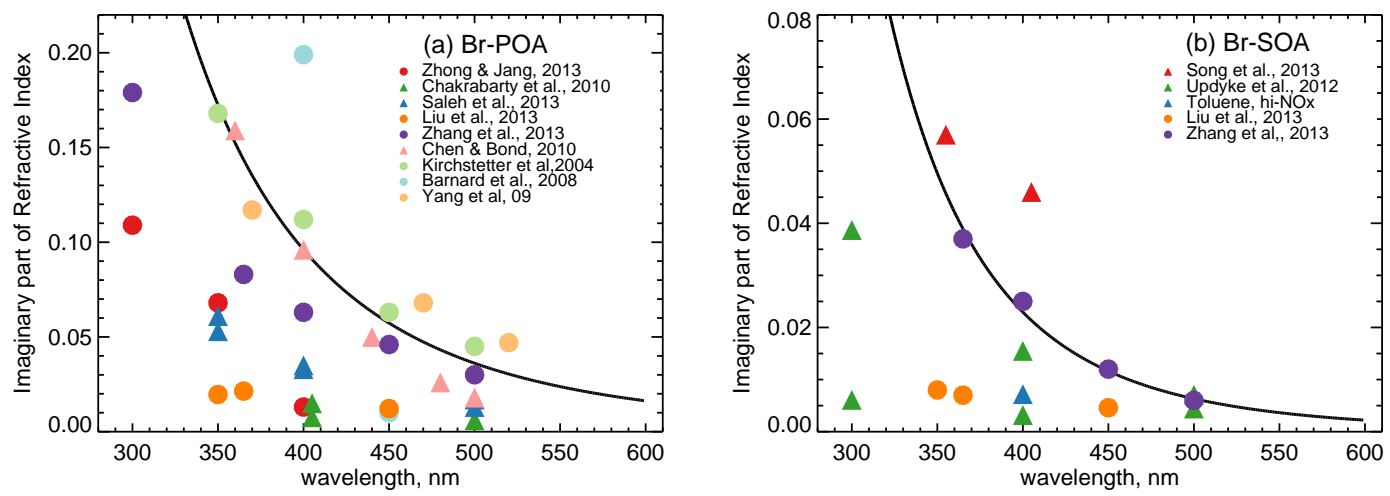

Figure 1. Summary of measured values for the imaginary part of the refractive index, $i$, for (a) Br-POA and (b) Br-SOA. Estimates from field studies are shown as circles; estimates from laboratory studies are shown as triangles. The black curves are used in our model. See Sect. 2.4 for detailed calculations.

methods from X. Y. Zhang et al. (2008) in 2006. In the US, we use the IMPROVE aerosol network (Interagency Monitoring of Protected Visual Environments, http://vista.cira. colostate.edu/improve/) observations from 2010, which measures BC using a filter-based thermal method. In Europe, we use the EMEP (The European Monitoring and Evaluation Program, http://www.emep.int/) observations, also in 2010. The EMEP measurement technique varies across sites, from filter-based thermal measurement to Aethalometer online optical measurements. All of these measurements cover at least three seasons.

\subsection{AERONET measurements}

The Aerosol Robotic Network (AERONET) is a global ground-based aerosol remote sensing network of radiometers (Dubovik and King, 2000; Holben et al., 2001). By measuring the spectral sky radiance in a wide angular range from the sun, AERONET retrieves spectral AOD and SSA for the atmospheric column overhead. Measurements are reported at four wavelengths (440, 675, 870 and $1020 \mathrm{~nm})$.

The latest AERONET product (version 2) includes two levels of data: 1.5 and 2. The level-1.5 AOD is automatically cloud cleared but not finally calibrated, such that the level2 data should be of higher quality. We use the mean AOD from 2000 to 2011 in order to compensate for sampling limitations and increase the robustness of our seasonal averages. The 12-year averaged global mean AOD at $440 \mathrm{~nm}$ is 0.29 in level-2 and similarly 0.27 in level-1.5. However, in specific regions or seasons, the difference between the two levels can be large. For example, in spring in China, the average AOD is about $40 \%$ higher in the level- 1.5 product than in the level-2 product. We therefore only use the high-quality level-2 AOD.

The level-2 SSA AERONET data are only available under high AOD conditions (AOD > 0.4 at $440 \mathrm{~nm}$ ) (Dubovik and King, 2000; Bahadur et al., 2012); this subset is only $20 \%$ of the level-1.5 measurements. This presents a challenge for interpreting the global SSA constraints provided by
AERONET: the level-2 data is of higher quality than the level 1.5 , but is biased towards high-aerosol loading conditions. The global average AAOD for the level-2 product (which can only be derived when AOD is high) is 0.058 at $440 \mathrm{~nm}$, but is only 0.026 in the level- 1.5 product, over a factor of 2 different. However, if we only consider the sites and times when level-2 SSA is retrieved and compare mean values with level 1.5 for the same periods, we find that AAOD is $15 \%$ lower at $440 \mathrm{~nm}$ in the level 1.5 data, suggesting a large data quality impact. To address this challenge when deriving AAOD we use level-2 SSA under both high and low AOD conditions, that is, we assume that the SSA is independent of AOD in a given season. This is reasonable if the aerosol composition at a given location is relatively constant throughout a given season. The overall AOD may vary because of a change in total aerosol loading, but SSA remains the same when the relative ratios among different species are constant. Bahadur et al. (2012) tested this assumption by showing that the SSA is not correlated with AOD, suggesting that the use of level-2 SSA for all AOD levels is unlikely to result in large biases.

The AAOD from AERONET does not only reflect the absorption from $\mathrm{BC}$ and $\mathrm{BrC}$, but also that from coarse dust. Based on previous studies (Dubovik et al., 2002; Chung et al., 2012; Russell et al., 2010), we use the extinction/absorption Ångström exponent to exclude data points highly affected by dust. In our comparison, data with extinction Ångström exponent < 1 and absorption Ångström exponent $>1.5$ are considered to be those highly affected by dust and are removed in our analysis. This exclusion decreases the global mean AERONET AOD and AAOD by 5 and $7 \%$, respectively (12 year mean, $440 \mathrm{~nm}$ ). There are additional uncertainties associated with AERONET measurements, such as those from the clear-sky sampling, which are discussed further in Sect. 6.2. 


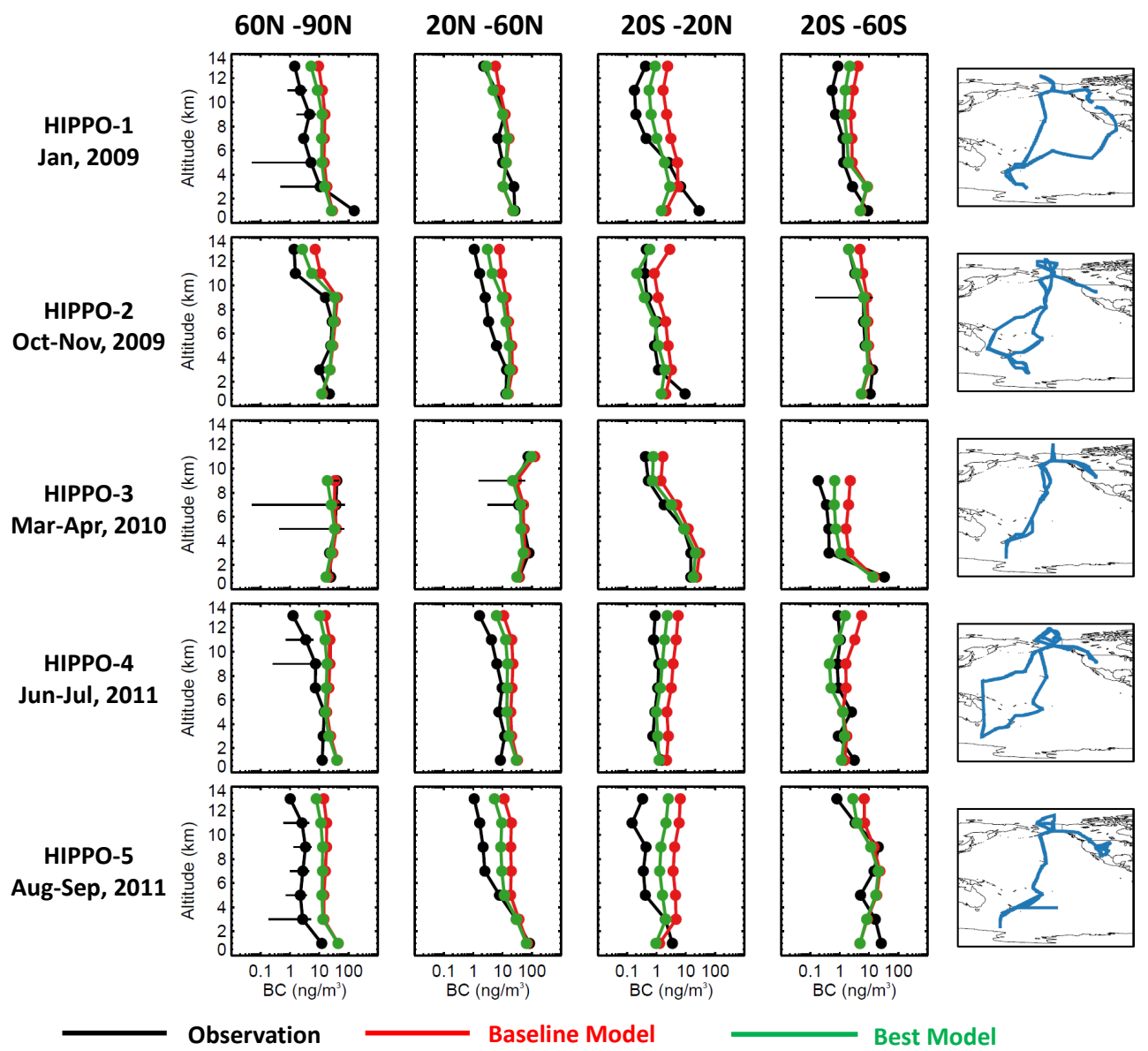

Figure 2. The mean vertical profile of BC mass concentrations (shown in $1 \mathrm{~km}$ bins) from the five HIPPO campaigns in 2009-2011, shown by region and different campaign (year and season). Observations (black) are compared with the "baseline" (red) and the "best" (green) GC-RT simulation. Error bars show the standard deviation of measurements averaged in each vertical bin. The last column shows the flight route for each campaign.

\section{Comparing simulated BC mass concentrations to observations}

We compare both the "baseline" and "best" modeled BC mass concentrations to observations. The only difference in the simulation of $\mathrm{BC}$ mass in these two schemes is the aging process. The meteorology and biomass-burning emissions used in the simulations are for the year corresponding to the observations.

\subsection{Remote measurements (HIPPO)}

The measurements from the HIPPO campaign are divided into four regions: around the equator $\left(20^{\circ} \mathrm{S}-20^{\circ} \mathrm{N}\right)$; the Northern Hemisphere $\left(20-60^{\circ} \mathrm{N}\right)$; the Southern Hemisphere $\left(20-67^{\circ} \mathrm{S}\right)$ and the Arctic $\left(60-80^{\circ} \mathrm{N}\right)$. Measurements in the equator and Southern Hemisphere regions generally reflect very clean background conditions. Occasionally, the Southern Hemisphere region can also be affected by biomass burning in Africa and South America. Both the equator and
Southern Hemisphere are ideal regions to examine the aging mechanisms in the model since continental air masses are well aged by the time they reach these locations. In contrast, the Northern Hemisphere and Arctic regions are more heavily influenced by anthropogenic emissions. Both of our "baseline" and "best" simulations are able to represent the vertical profile of observed $\mathrm{BC}$ concentrations. In addition, the updated aging in the "best" simulation shows improvement over the "baseline" in the mid-troposphere nearly in all regions (e.g., Fig. 2, row 3, column 3); however, it still underestimates the observation at upper altitudes in several regions (e.g., row 5, column 1). The model bias varies with region and season. The "best" model simulation of BC concentrations is within a factor of 2 for $85 \%$ of the data points and within a factor of 3 for $96 \%$ of the measurements.

Figure 3 shows the frequency distribution of observed and modeled BC concentrations. At the equator, our "best" simulation captures the peak of observed concentrations better than the "baseline" simulation. However, in the other three regions, particularly the two regions in the Northern 

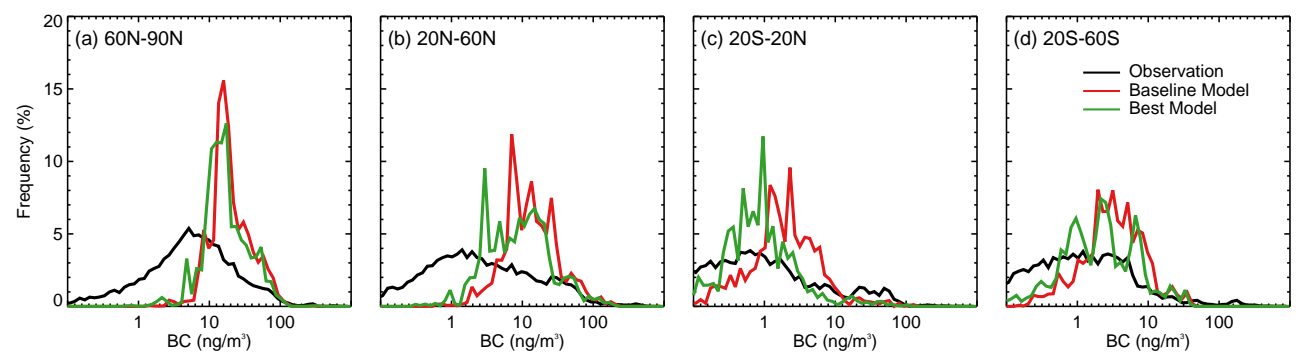

Figure 3. Frequency distribution of observed (black) and "baseline" (red) and "best" (green) simulated black carbon concentrations during all five HIPPO campaigns from 2009-2011, shown by region.
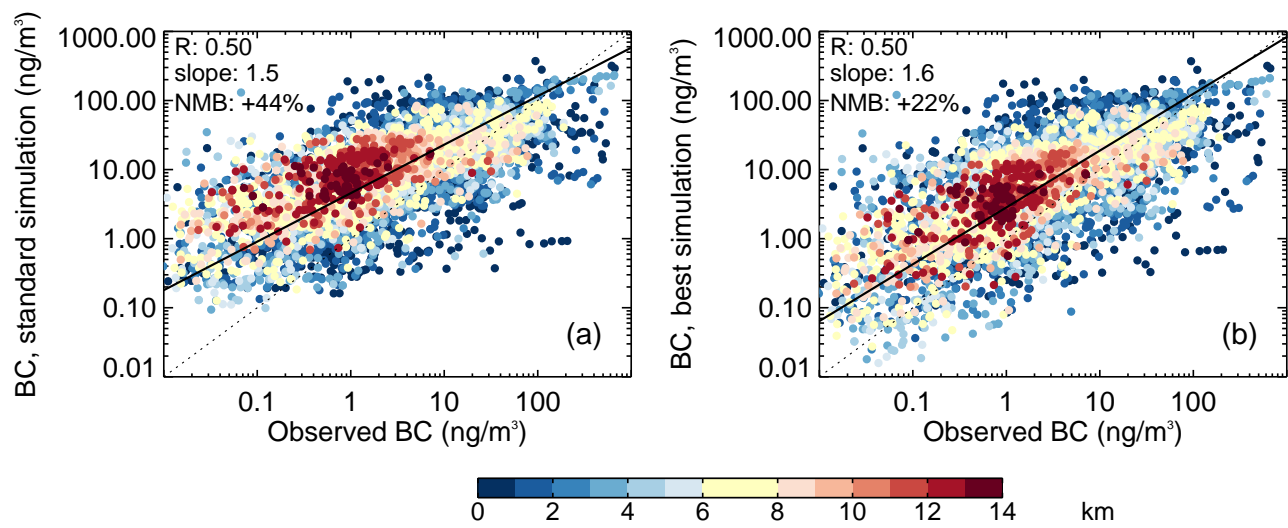

Figure 4. Point-to-point comparison of observed and simulated BC mass concentrations from the HIPPO aircraft campaign for (a) the "baseline" simulation and (b) the "best" simulation. The color bar shows the altitude of the aircraft measurements. The 1-to-1 line is shown as a dotted black line, the best-fit line is shown as a black solid line. NMB: normalized mean bias between modeled and observed data.

Hemisphere, neither of our simulations are able to capture the observed low concentrations. These bias between model and observation may be associated with errors in the model description of scavenging, emissions or transport, or any combination of these. This includes the inability of a coarse-grid Eulerian model to reproduce the BC concentration gradients within a grid box, the effect of which is likely strongest near source where clean air mixes with freshly emitted plumes (Rastigejev et al., 2010; Vignati et al., 2010).

Figure 4 compares the overall model performance for the "baseline" and "best" simulations of the HIPPO campaigns. Overall, the "baseline" model overestimates BC concentrations by $44 \%$, with larger bias at high altitudes. This bias is substantially reduced in the "best" model (22\% overestimate). Although the model bias varies, in most regions the model still overestimates BC concentrations at mid-altitudes, even with our faster aging mechanisms. It is unclear whether this bias is connected to anthropogenic or biomass-burning BC. We have conducted a series of sensitivity tests by varying assumptions in our aging mechanisms and the scavenging rate, but there is no simple adjustment that better represents the entirety of the HIPPO data. Our simple aging scheme may not be suitable for all environments. The shape and size of $\mathrm{BC}$ as well as the co-emitted species may vary consider- ably regionally and seasonally, which could give rise to different aging efficiency. Bias in the amount and location of precipitation in the GEOS-5 product may also play a role. However, in general we conclude that the model simulation in remote areas is not markedly biased, and that our model, including an updated aging scheme, represents the low BC concentrations over remote regions substantially better than previous model studies (Koch et al., 2009; Schwarz et al., 2010).

\subsection{Near-source measurements}

Figure 5 compares the simulation and observations of BC mass concentrations during the ARCTAS and EUCAARI campaigns. The model simulation more accurately reproduces the magnitude and vertical profile of $\mathrm{BC}$ in these nearsource areas than the remote HIPPO observations (note the linear scale on plots), which suggests that the bias in emissions is less significant than the biases in aging, transport, and removal. There is also little difference between our "baseline" and "best" simulations here, demonstrating how aging does not control near-source BC mass concentrations. The spring measurements (Fig. 5a and c) are affected by biomassburning plumes in the free troposphere (peak $\sim 4 \mathrm{~km}$ ) (Wang et al., 2011), which are not captured by the model. The model 

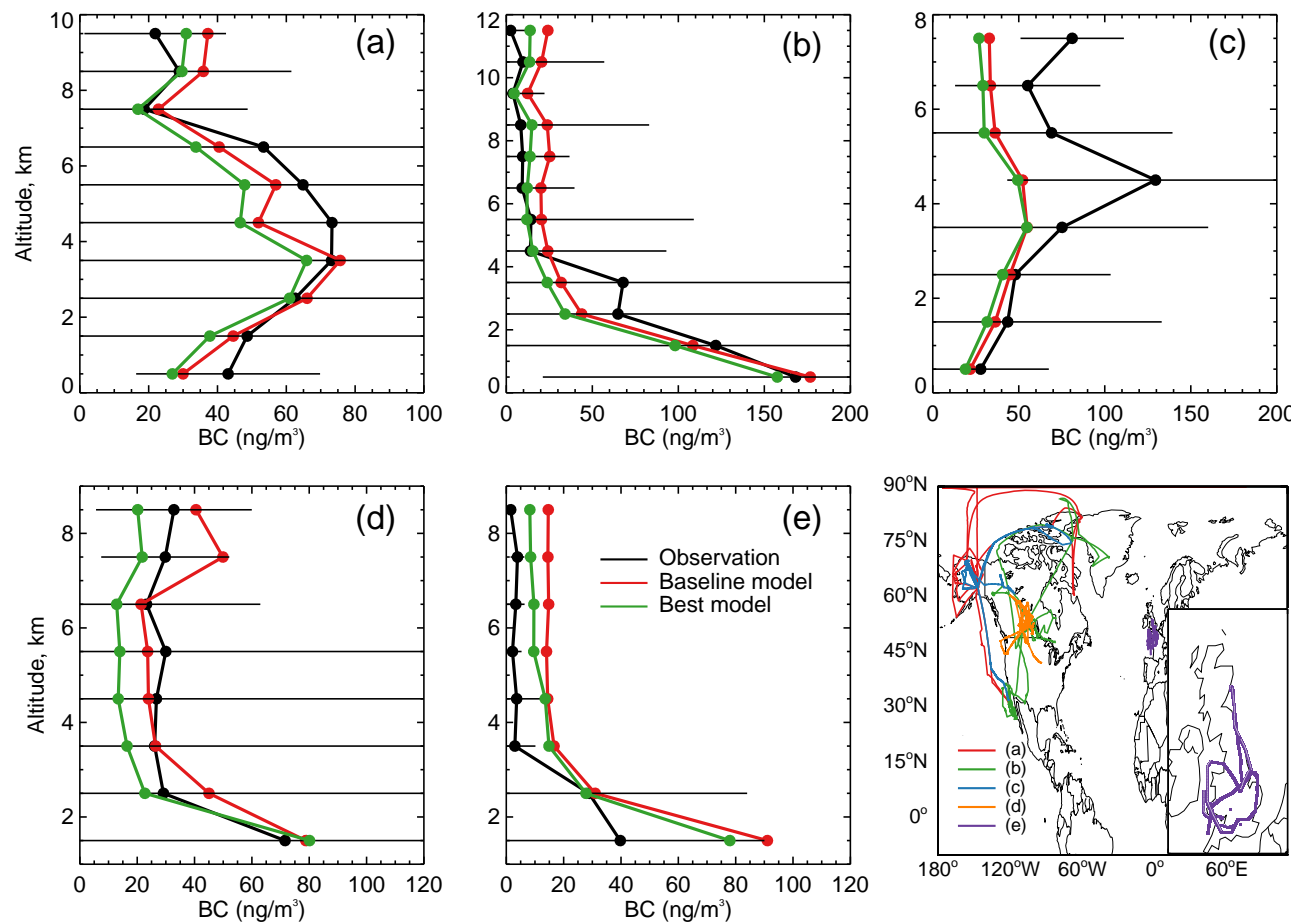

Figure 5. The observed (black) and "baseline" (red) and "best" (green) simulated black carbon median vertical profile during (a) ARCTAS DC8, April 2008; (b) ARCTAS DC8, June-July 2008; (c) ARCTAS P3B, April 2008; (d) ARCTAS P3B, June-July 2008 and (e) EUCAARI, April and September 2008. The related flight tracks are shown on the bottom right corner. The error bars show the standard deviations of measurements averaged in each vertical bin. Note the different scale among panels.

skill is much higher in the summer (Fig. $5 b$ and d), when fire is not an important source. Overall, the "best" model simulation of BC concentrations is within a factor of 2 for $97 \%$ of the ARCTAS data points, with a mean bias of $-20 \%$. The EUCAARI observations of BC concentrations in the free troposphere are very low $\left(<5 \mathrm{ng} \mathrm{m}^{-3}\right.$ above $\left.3 \mathrm{~km}\right)$, similar to the background concentrations reported for the HIPPO campaigns. With the exception of the time shortly after aircraft take off and before landing, the EUCAARI flight path traverses relatively clean marine regions around UK. However, all of the model grid boxes in this region include both land and sea; therefore the model BC mass concentrations are overestimated in this region (mean $+95 \%$ bias), particularly near the surface. At high altitude, which is associated more with regional mean conditions than the local sources, the absolute model bias is smaller. All of the simulated mean values are within the standard deviation of the near-source airborne measurements except for those in the upper-troposphere during EUCAARI.

We also compare the modeled surface concentrations to surface measurements in three regions dominated by anthropogenic emissions: China, the US and Europe. Figure 6 shows that our "best" model underestimates the surface BC in China $(-21 \%)$ and Europe $(-29 \%)$, but overestimates in the US $(+28 \%)$. Biases in China and Europe are both largely the result of individual sites with high $\mathrm{BC}$ concen- trations which likely reflect very local sources (Dunhuang in west China and Ispra in Italy). When excluding the observations from these two sites, the overall model bias decreases to $-6 \%$ in China and $-5 \%$ in Europe. The overestimate over the US is likely associated with the decreasing trend of aerosol emissions after 2000 (Leibensperger et al., 2012), the year of the Bond et al. (2007) emission inventory used in the model.

To summarize, our near-source comparisons show that our "best" simulation of BC concentrations is within a factor of 2 of observations at most altitudes and within $30 \%$ at the surface.

\section{Comparing simulated and AERONET regional AAOD}

As shown in Sect. 4, the mean bias of our simulation of BC mass concentrations is generally small in both source and remote regions compared to the model errors shown in previous studies (Koch et al., 2009; Schwarz et al., 2008b). In this section, we compare our simulation with AERONET AAOD observations which integrate both $\mathrm{BC}$ mass and optical properties. For this comparison, biomass-burning emissions are averaged for 12 years to compare with the 12-year average of AERONET data. The meteorology is for the year 2010. 


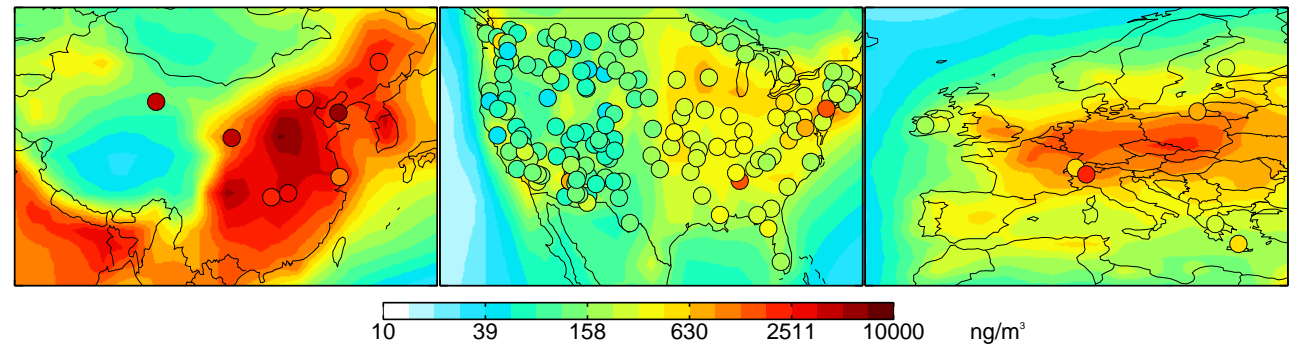

Figure 6. Annual mean surface BC concentrations in China (left), the US (middle) and Europe in the "best" model in 2010 and observations (overlaid with circles). Observations in China are from 2006 except for the sites near Beijing and Shanghai. All the other observations are from 2010 .

Figure 7 shows the "best" modeled annual average AAOD at 440 and $675 \mathrm{~nm}$ together with AERONET data. In most regions, the baseline model underestimates the AERONET AAOD at both wavelengths, but the bias decreases as we increase the absorption in the model. Large model biases remain in the biomass-burning regions of Africa, India and Southeast Asia. In the following analysis, we focus on the regionally averaged AAOD within five regions (selected for diversity and minimum dust influence), which are shown as red boxes in Fig. 7. The model simulation in each region is sampled to the locations of AERONET sites. Detailed comparisons of AAOD in these regions are shown in Fig. 8. The vertical error bars show the standard deviations of regional annual average values, which represent the inter-annual variability in measured AAOD. Since we assume that the SSA is temporally constant at each site, these standard deviations are only associated with AOD. The black dashed lines show an alternative averaging of AERONET data, here we use the AERONET level 1.5 SSA when the level 2.0 SSA is not available. This this procedure generates nearly identical average AAOD in East Asia and South Africa. In the other three regions, the difference between the two data processing methods is less than $30 \%$; this uncertainty will be discussed further in Sect. 6.3.

Figure 8a, b and c show that the "baseline" simulation underestimates the observations and fails to capture the wavelength dependence of AAOD in these anthropogenically influenced regions. The bias in the "baseline" simulation increases with decreasing wavelength, from $30 \%$ at 675 and $870 \mathrm{~nm}$ to about $60 \%$ at $440 \mathrm{~nm}$. While Fig. 8 only shows annual average values, the results are generally consistent across seasons, but with smaller biases in US spring, east Asian winter and European spring. The differences in each season are within $\pm 20 \%$ of the annual average in both observations and simulations. The "best" simulation shows substantial improvement over the "baseline" simulation, but still underestimates the observed AAOD. The green shaded regions shows the range of "best" simulated results related to uncertainties in size distribution $(\mathrm{GMD}=20$ to $200 \mathrm{~nm}$, $\delta=1.3$ to 2.2$)$, refractive index (1.75-0.63i to $1.95-0.79 i$, the range suggested by Bond and Bergstrom, 2006), hygro-
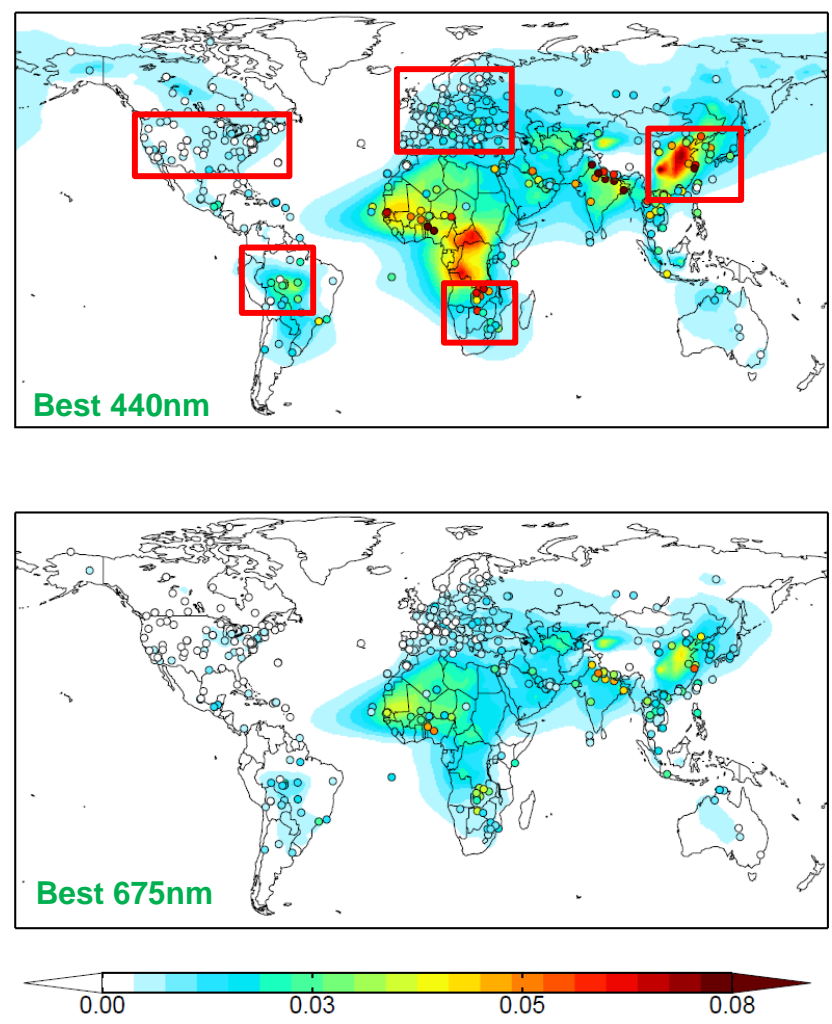

Figure 7. The annual mean simulated AAOD at $440 \mathrm{~nm}$ (upper) and $670 \mathrm{~nm}$ (lower) from the "best" simulation. The circles indicate the 12-year average observed AAOD at AERONET sites. The red boxes in the upper figure show the analysis regions discussed in Sect. 5 and shown in Fig. 8.

scopic growth (no growth and double the growth) and the aged fraction of $\mathrm{BC}$ to which absorption enhancement is applied (consider all BC are aged or only hydrophilic BC are aged). Our "best" simulation is near the top of this range; uncertainty in these assumptions produce at most an $8 \%$ increase in the AAOD (the higher end of shading) and cannot account for model-measurement differences. The "best" simulation also shows an improved representation of the 

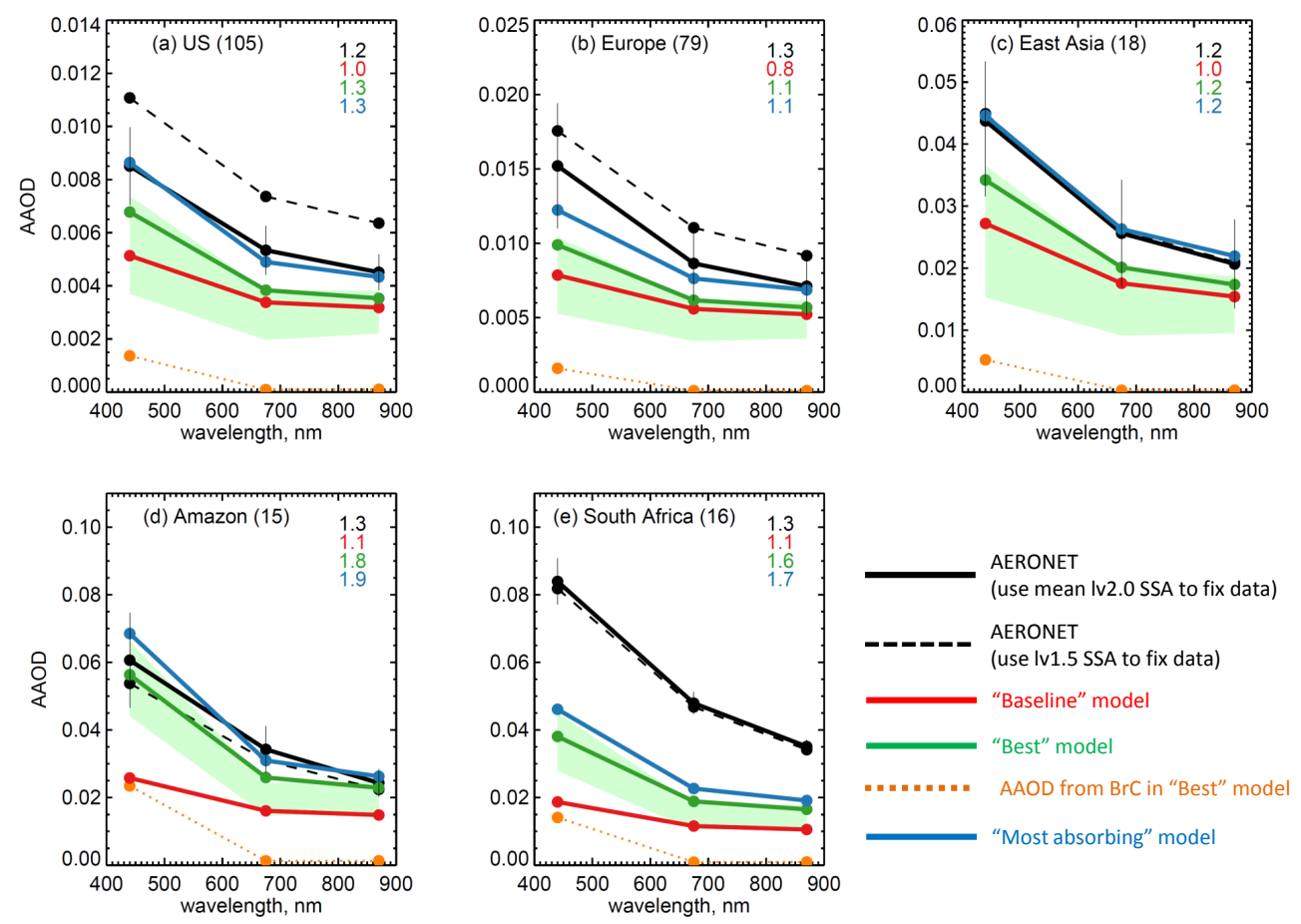

Figure 8. The regional mean wavelength-dependent AAOD at AERONET sites in (a) US, (b) East Asia, (c) Europe, (d) Amazon and (e) South Africa (regions defined by red boxes in Fig. 7). Averages are annual for (a-c) and for the fire season in (d-e). The available number of sites averaged in each region are shown in brackets. Numbers at the upper-right corner of each panel indicate the absorption Ångström exponent $(440 \mathrm{~nm} / 675 \mathrm{~nm})$. Observations are shown in black, with three model simulations: "baseline" (red), "best" (green), "most absorbing" (blue). The contribution from brown carbon is shown in brown. Error bars show the standard deviation of observed annual AERONET AAOD. Green shadings show the range of "best" modeled AAOD when changing BC properties independent of BC mass and absorption enhancement, see text for detail.

wavelength dependence of AAOD; the absorption Ångström exponent increased from 1.0 or smaller in our "baseline" simulation to values much closer to AERONET observations (around 1.3). This improvement is associated with the inclusion of $\mathrm{BrC}$ which enhances absorption in the UV (Fig. 1). As shown with the brown lines in Fig. 8, BrC contributes 25, 15 and $20 \%$ of the total simulated AAOD at $440 \mathrm{~nm}$ in the US, East Asia, and Europe.

The "most absorbing" simulations almost exactly match the AAOD observations in the US and East Asia, but still modestly underestimate observations in Europe. This comparison suggests that the AAOD bias can be eliminated by using an $\mathrm{AE}$ of 2 (the upper limit of acceptable values) without increasing BC mass in specific regions. Since other uncertainties in BC properties (described by green shadings) fail to account for the model bias, we suggest that the bias between our "best" simulation and the AERONET observations are the result of an underestimate of either or both $\mathrm{AE}$ and $\mathrm{BC}$ mass. Indeed, the same fractional increase of AE or $\mathrm{BC}$ mass concentrations in our model produce very similar increases in simulated AAOD. Our evaluation of mass concentrations in Sect. 4, suggest that a bias in emissions is unlikely for these regions. However, in Europe, a $30 \%$ increase in biofuel emissions (both $\mathrm{BC}$ and $\mathrm{OA}$ ) would improve the simulation of both AAOD and absorption Ångström exponent (AAE). Alternatively, the underestimate in this region may be the result of neglecting the contribution of nitrate to absorption enhancement, which has been shown to contribute to BC coatings in Europe (Liu et al., 2013).

In biomass-burning dominated regions (Fig. 8d and e), the comparisons are only for the fire season (August to September). Biomass-burning emissions in these two months dominate the total annual $\mathrm{BC}$ emissions in both the Amazon and South Africa, and provide an opportunity to evaluate our biomass-burning $\mathrm{BC}$ and $\mathrm{BrC}$ assumptions. However, such comparisons are more challenging than in anthropogenically influenced regions because the number of sites is not large enough to capture all the areas influenced by fire plumes. In these regions, while the AAE is underestimated in the "baseline" simulation, the inclusion of substantial $\mathrm{BrC}$ from biomass-burning sources leads to an overestimate of the AAE in the "best" simulation. In comparison with the anthropogenically dominated regions, this suggests that either the emissions or absorption of $\mathrm{BrC}$ from biomassburning sources is too high. Alternatively, a $30 \%$ increase of $\mathrm{BC}$ emission from biomass burning, which is also very uncertain, would also bring the model into agreement with observed AAE. However, given that the bias in the "best" 

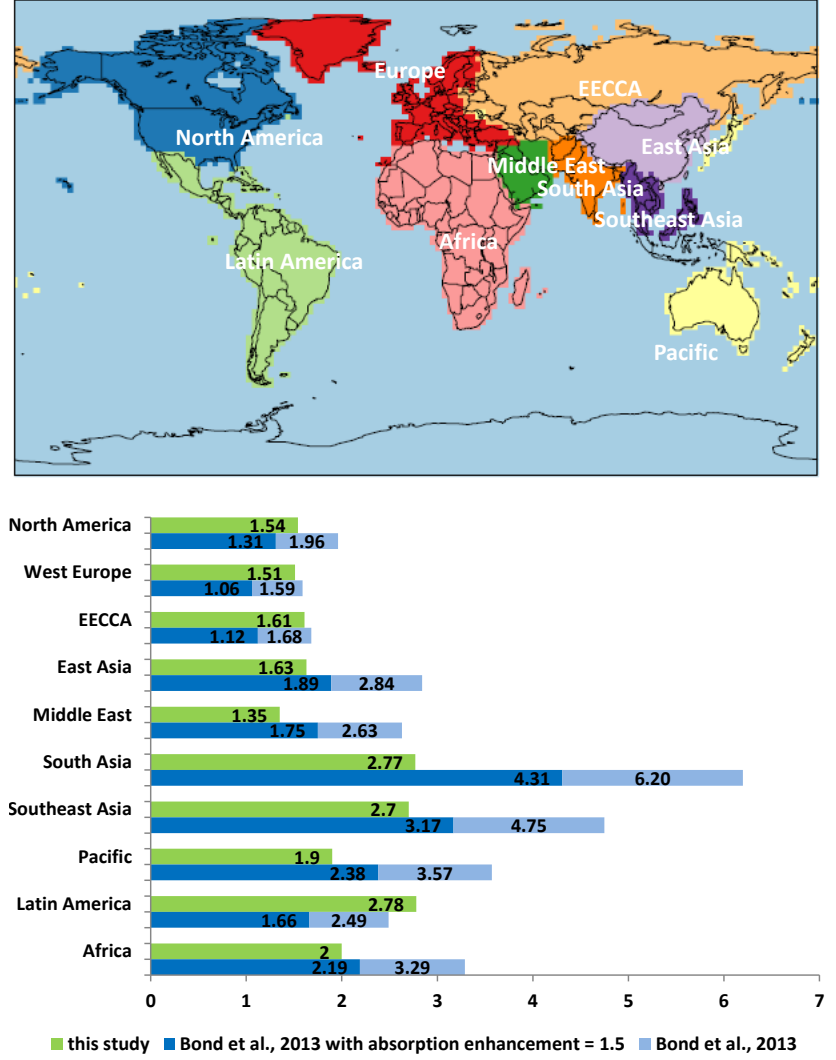

Figure 9. Top: region groups defined in Sect. 5 based on Supplement Table S1 in Bond et al. (2013). EECCA = eastern Europe, the Caucasus and Central Asia. Bottom: the ratio of mean regional AERONET AAOD to "best" modeled AAOD (green, average value over selected AERONET sites in Sect. 5.2) and mean regional AERONET AAOD to mean regional AeroCom I AAOD (light blue, average value over selected AERONET sites defined in Bond et al., 2013). The bar with dark blue indicates the ratios when an absorption enhancement of 1.5 was uniformly applied.

simulation of AAOD is less than $20 \%$ at all wavelengths in the Amazon (Fig. 5e), there is little justification for any further changes in the treatment of $\mathrm{BrC}$ or biomass-burning emission factors in this region.

The large bias in South Africa is likely due to the underestimate of both the poorly constrained emission factors for biomass burning (Bond et al., 2013) and the uncertainty of burned area. The GFED3 emissions used here are close to the FINNv1 (The Fire Inventory from NCAR version 1.0, Wiedinmyer et al., 2011) estimates for South Africa, but a factor of 2 smaller than the AMMA (the Multidisciplinary Analysis of African Monsoon program) inventory (Liousse et al., 2010), which suggests that significant burning in African savanna and grasslands are underestimated in GFED3.

We note that the absorption enhancement applied here is a proxy for the lensing effect, or any other factor which enhances absorption beyond standard spherical Mie calcula- tions. These factors (e.g., geometry) may also contribute to the model underestimate of AAOD.

To generalize this comparison to the global scale, the global land area is divided into 10 regions following the definitions of Bond et al. (2013), shown in Fig. 9. In most groups, the bias in the "best" modeled AAOD are consistent at 440 and $675 \mathrm{~nm}$. However, in North America, Latin America and Southeast Asia, the model bias at $675 \mathrm{~nm}$ is larger than at $440 \mathrm{~nm}$, which suggests that we overestimate the $\mathrm{BrC}$ absorption in these regions. In contrast, model bias of AAOD at $440 \mathrm{~nm}$ is much larger than at $675 \mathrm{~nm}$ in the Middle East, where the emissions are dominated by biofuel. This suggests that we may underestimate the $\mathrm{BrC}$ absorption from biofuel in the Middle East. Figure 9 shows the ratio of observed AAOD to modeled AAOD at $550 \mathrm{~nm}$ to describe the overall model bias in each region. All the ratios are smaller than 2, except for biomass-burning regions (South Asia, Southeast Asia, Latin America and Africa), where uncertainty associated with emission factors is high and observations are limited. Figure 9 also shows the same ratio from Bond et al. (2013) who compared the $550 \mathrm{~nm}$ AAOD in the AeroCom I model mean to AERONET observations. The original ratios (light blue bars) from the AeroCom models are larger than our estimate in all regions except Latin America. The AeroCom I models, used in Bond et al. (2013) do not treat $\mathrm{BC}$ as internally mixed or consider the absorption enhancement from $\mathrm{BC}$ coating, and therefore underestimate the AAOD, resulting in larger biases. When Bond et al. (2013) apply an absorption enhancement of 1.5 to all the simulated AAOD, the ratios (dark blue bars) are closer to one than our values in North America, western Europe and EECCA (Eastern Europe, the Caucasus and Central Asia), resulting from our assumption of a smaller enhancement of 1.1 for fossilBC. Furthermore, the omission of $\mathrm{BrC}$, leads to larger underestimates of absorption in Bond et al. (2013), particularly in high OA regions. In addition, Bond et al. (2013) apply absorption enhancement to all BC (not separating fresh and aged) and they apply a uniform SSA assumption of 0.36 to calculate the simulated AAOD $(550 \mathrm{~nm})$, which ignores the spatial and seasonal variation of SSA. In our simulations, the SSA of BC varies from 0.2 to 0.4 at $550 \mathrm{~nm}$ in different season and region.

\section{Estimating the direct radiative forcing (DRF) of $\mathrm{BC}$}

\subsection{DRE and DRF in GC-RT}

We now estimate the DRF (from pre-industrial to presentday) associated with our $\mathrm{BC}$ simulations and explore the uncertainties in this estimates. We first estimate the direct radiative effect (DRE), the flux perturbation associated with the present-day burden of all BC. The BC DRE and DRF for our "best" simulation are shown in Fig. 10; global mean 

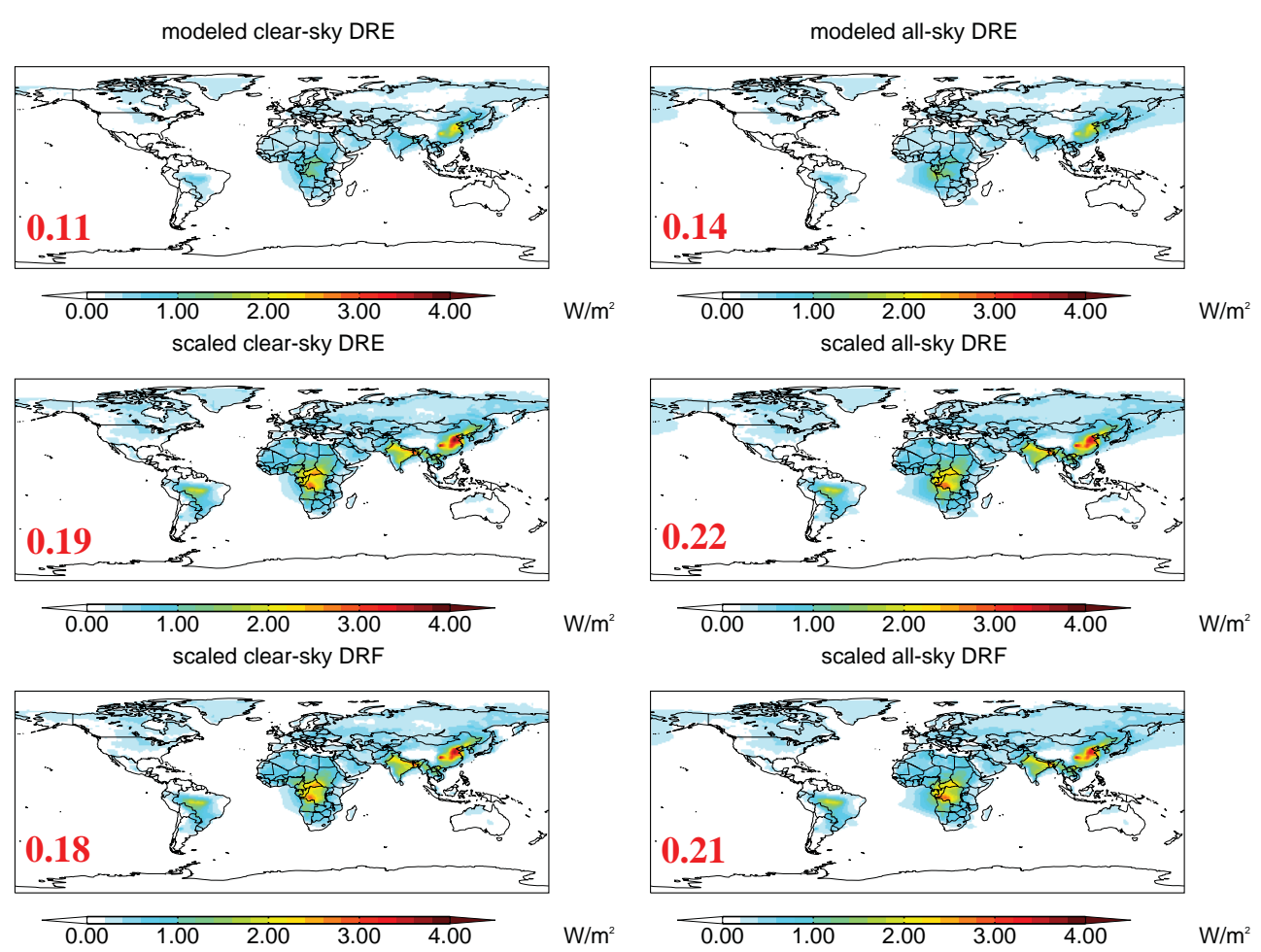

Figure 10. The global annual mean BC DRE at the top atmosphere (TOA) in the "best" model, scaled DRE and scaled DRF in 2010 at both clear-sky and all-sky conditions. Numbers in red indicate the global mean value.

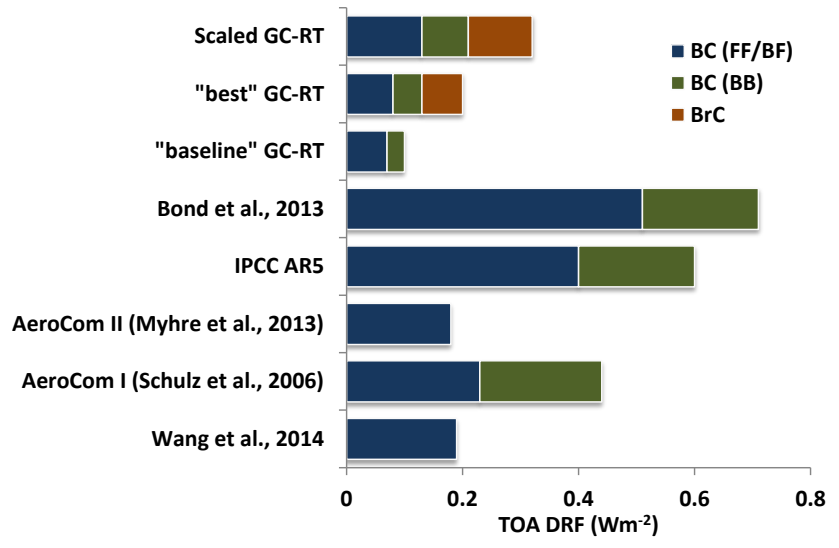

Figure 11. Comparison of our GC-RT estimate of global average DRF of BC compared to other studies. DRF is show by source type ( $\mathrm{FF}=$ fossil fuel, $\mathrm{BF}=$ biofuel, $\mathrm{BB}=$ biomass burning). We also show the absorption DRF from $\mathrm{BrC}$.

values are 0.14 and $0.13 \mathrm{Wm}^{-2}$ for all-sky condition. The DRF includes $0.08 \mathrm{Wm}^{-2}$ from anthropogenic sources and $0.05 \mathrm{Wm}^{-2}$ from biomass burning.

Following the analysis in Sect. 5 and as done in Bond et al. (2013), we provide an alternate estimate of the DRF by scaling the AAOD to match the AERONET observational constraints based on the ratios shown in Fig. 9. We do not apply the scaling over oceans, given the lack of measurement constraint over the ocean (discussed further in Sect. 6.2). The global mean AAOD at $550 \mathrm{~nm}$ is 0.0014 before the scaling and 0.0024 after scaling for $\mathrm{BC}, 0.0005$ before the scaling and 0.0008 after scaling for $\mathrm{BrC}$. $\mathrm{BrC}$ contributes $25 \%$ of the total AAOD from carbonaceous aerosols, which is similar to the measurement-based estimate of Chung et al. (2012) $(20 \%)$. The global mean all-sky DRF associated with this observationally scaled simulation is $0.21 \mathrm{Wm}^{-2}$ for BC $\left(0.13 \mathrm{Wm}^{-2}\right.$ anthropogenic, $0.08 \mathrm{Wm}^{-2}$ biomass burning). After scaling, the DRF of $\mathrm{BrC}$ is $-0.02 \mathrm{Wm}^{-2}$. Although the $\mathrm{DRF}$ of $\mathrm{BrC}$ is negative, it is only slightly scattering compared to POA. The DRF of total OA increases from $-0.32 \mathrm{Wm}^{-2}$ in the baseline simulation to $-0.25 \mathrm{Wm}^{-2}$ when including absorption from $\mathrm{BrC}$, we therefore estimate an absorption DRF from $\mathrm{BrC}$ of $+0.07 \mathrm{Wm}^{-2}$. If we do not consider $\mathrm{BrC}$ and assume the difference between modeled and observed AAOD must be attributed solely to BC, the DRF of BC increases to $0.32 \mathrm{Wm}^{-2}$.

We can compare of $\mathrm{BrC}$ simulation and resulting forcing to previous studies. Feng et al. (2013) base their BrC optical properties on Chen and Bond (2010) (smaller than the pink triangles in Fig. 1a, since they choose a different burning condition) and Kirchstetter et al. (2004) (light green circles in Fig. 1a) and treat $66 \%$ of the POA from biofuel and biomass burning as Br-POA. They do not include any secondary sources of BrC. The biomass-burning emissions employed 
Fraction of $\mathrm{BC}$ load above $5 \mathrm{~km}$
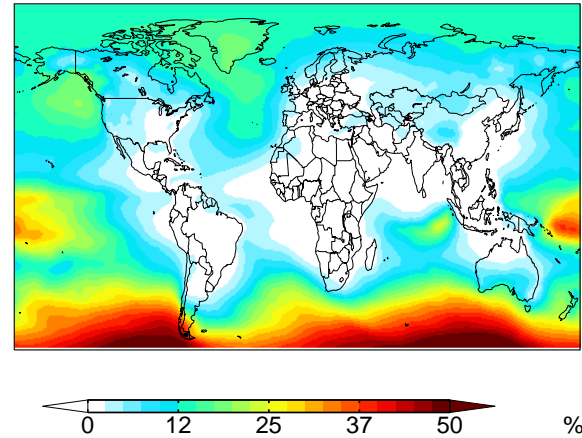

Absorption forcing efficientcy (AFE) of BC
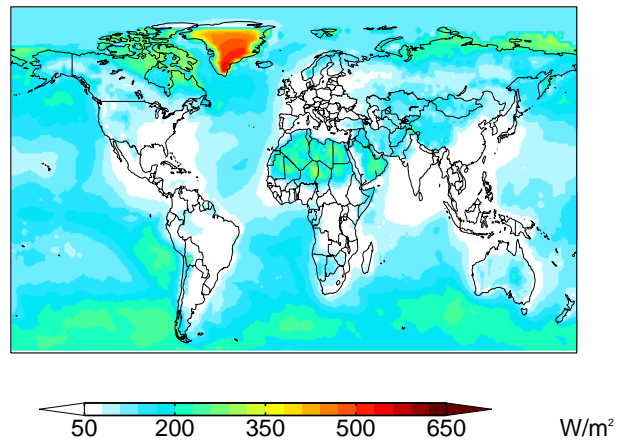

Figure 12. Global distribution of the fraction of BC mass load over $5 \mathrm{~km}$ (left) and BC absorption forcing efficiency (right, $\mathrm{AFE}=\mathrm{DRE} / \mathrm{AAOD}$ at $550 \mathrm{~nm})$.

Table 2. Global average of mass and optical related properties of BC in GC-RT (for year 2010) and other studies. Note that pre-industrial emissions in our study and AeroCom models are the same (Dentener et al., 2006).

\begin{tabular}{|c|c|c|c|c|c|c|c|c|c|c|c|c|}
\hline Reference & $\begin{array}{r}\text { emission } \\
\left(\mathrm{Tg} \mathrm{yr}^{-1}\right)\end{array}$ & $\begin{array}{r}\text { lifetime } \\
\text { (day) }\end{array}$ & $\begin{array}{r}\text { load } \\
\left(\mathrm{mg} \mathrm{m}^{-2}\right)\end{array}$ & $\begin{array}{r}\text { load above } \\
5 \mathrm{~km}(\%)\end{array}$ & $\begin{array}{r}550 \mathrm{~nm} \text { AAOD } \\
\times 1000\end{array}$ & $\begin{array}{r}\text { TOA DRE } \\
\left(\mathrm{Wm}^{-2}\right)\end{array}$ & $\begin{array}{r}\text { TOA DRF } \\
\left(\mathrm{Wm}^{-2}\right)\end{array}$ & $\begin{array}{r}\mathrm{AFE}^{\mathrm{b}} \\
\left(\mathrm{Wm}^{-2}\right)\end{array}$ & $\begin{array}{l}\mathrm{NDRE}^{\mathrm{c}} \\
\left(\mathrm{Wg}^{-1}\right)\end{array}$ & $\begin{array}{r}\text { scaled } 550 \mathrm{~nm} \\
\text { AAOD } \times 1000\end{array}$ & $\begin{array}{r}\text { scaled TOA DRE } \\
\left(\mathrm{Wm}^{-2}\right)\end{array}$ & $\begin{array}{r}\text { scaled TOA DRF } \\
\left(\mathrm{Wm}^{-2}\right)\end{array}$ \\
\hline baseline GC-RT in this study & $6.9(4.9)^{\mathrm{a}}$ & 4.9 & $0.18(0.11)$ & 17 & $1.12(0.70)$ & $0.11(0.07)$ & $0.10(0.07)$ & 98 & 610 & & & \\
\hline "best" GC-RT in this study & $6.9(4.9)$ & 4.4 & $0.16(0.10)$ & 12 & $1.40(0.85)$ & $0.14(0.08)$ & $0.13(0.08)$ & 100 & 880 & $2.44(1.50)$ & $0.22(0.13)$ & $0.21(0.13)$ \\
\hline Bond et al. $(2013)^{\mathrm{d}}$ & & & & & $2.12(1.72)$ & & & 171 & & $6.05\left(4.89^{\mathrm{e}}\right)$ & 0.88 & $0.71(0.51)$ \\
\hline Schulz et al. $(2006)^{\mathrm{f}}$ & (6.3) & (7.3) & $(0.25)$ & (21) & $(1.90)$ & $(0.29)$ & $(0.25)$ & (153) & $(1160)$ & & & \\
\hline Myhre et al. (2013) $)^{\mathrm{g}}$ & & & $(0.14)$ & & & $(0.20)$ & $(0.18)$ & & (1438) & & & \\
\hline Wang et al. $(2014)^{\mathrm{h}}$ & 6.5 & 4.2 & 0.15 & 9 & 1.70 & & 0.19 & $114^{i}$ & & 2.60 & & 0.31 \\
\hline
\end{tabular}

in this study, are about $40 \%$ higher than our biomass-burning source based on the 12-year GFED3 average. This results in a $170 \%$ larger global $\mathrm{BrC}$ source $\left(30.3 \mathrm{Tg} \mathrm{yr}^{-1}\right)$, but a similar global BrC DRF $\left(+0.04\right.$ to $\left.+0.11 \mathrm{Wm}^{-2}\right)$. Notice that our DRF value is scaled to meet AERONET data. In contrast, Lin et al. (2014) estimate a much larger DRF for $\mathrm{BrC}(+0.22$ to $+0.57 \mathrm{Wm}^{-2}$ ). Their optical properties for primary $\mathrm{BrC}$ are also based on Chen and Bond (2010) and Kirchstetter et al. (2004). However they also treat all SOA as BrC and apply these same absorption properties to the $\mathrm{Br}-\mathrm{SOA}$, resulting in an unrealistically high estimate of BrC DRF.

Figure 11 compares the DRF between previous studies and our estimates, including disaggregation by source type. Table 2 summarizes the related BC budget and properties for these studies (Bond et al., 2013; Myhre et al., 2013; Schulz et al., 2006; Wang et al., 2014; IPCC, 2013). Our "best" estimated $\mathrm{BC}$ load $\left(0.16 \mathrm{mg} \mathrm{m}^{-2}\right)$ and lifetime (4.4 days) are slightly higher than the estimate $\left(0.15 \mathrm{mg} \mathrm{m}^{-2}\right.$ and 4.2 days $)$ of Wang et al. (2014) who also use the GEOS-Chem model. This difference is primarily the result of their treatment of hydrophobic BC as ice nuclei in cold clouds; implementing this in our simulations has little impact given that our fast aging has converted most hydrophobic BC to hydrophilic before transport to high altitudes. They also suggest that their treatment could overestimate the scavenging of $\mathrm{BC}$ and is inconsistent with some ice nucleation studies (Friedman et al., 2011). They also use the default GEOS-Chem assumptions for the refractive index and density of BC (see Sect. 2) which produce an AAOD at $550 \mathrm{~nm}$ and DRF which are 20 and $45 \%$ higher than this study, though their BC mass load is lower.

Conversely, the mass load of BC in our "best" model is substantially smaller than most of the AeroCom models (both phase I from Schulz et al., 2006 and phase II from Myhre et al., 2013), which overestimate BC mass concentrations at high altitudes and remote locations (a factor of 3 to 15 , Koch et al., 2009). Even with our shorter lifetime, the modeled BC in our "best" simulation is still higher than observations over much of the remote oceans (Sect. 4.1), which indicates that the $\mathrm{BC}$ mass load and lifetime are likely even lower than our estimates. However we show that our simulation of AAOD (including $\mathrm{BrC}$ ) is less biased than the AeroCom models at AERONET sites. Our simulation also has lower BC absorption forcing efficiency (AFE) than AeroCom models. This is associated with the lower lifetime which particularly decreases concentrations at high altitudes. The fraction of BC load above $5 \mathrm{~km}$ is $12 \%$ in our model, compared to $21 \%$ in AeroCom phase I models. Figure 12 shows the fraction of $\mathrm{BC}$ load above $5 \mathrm{~km}$ and the AFE distribution in our "best" simulation. Excluding the Antarctic region (with extremely low BC and AAOD) these two factors are moderately correlated $(R=0.6)$. A greater fraction of $\mathrm{BC}$ at high 
Table 3. Summary of the uncertainties in DRE and DRF estimates.

\begin{tabular}{|c|c|c|}
\hline \multirow{2}{*}{ Uncertainty source } & \multicolumn{2}{|c|}{ Uncertainty } \\
\hline & DRE & DRF \\
\hline AERONET AAOD retrieval & $+100 \%$ & $+100 \%$ \\
\hline AERONET clear-sky sampling & $\pm 4 \%$ & $\pm 4 \%$ \\
\hline AAOD scaling & $-40 \% /+65 \%$ & $-40 \% /+65 \%$ \\
\hline & $( \pm 30 \%$ on land, $-50 \% /+100 \%$ in ocean) & ( $\pm 30 \%$ on land, $-50 \% /+100 \%$ in ocean) \\
\hline Dust impact & $\pm 65 \%$ & $\pm 65 \%$ \\
\hline BrC impact & $-20 \% /+40 \%$ & $-20 \% /+40 \%$ \\
\hline Vertical distribution & $\pm 35 \%$ & $\pm 35 \%$ \\
\hline pre-industrial scaling & - & $-10 \%$ \\
\hline Total uncertainty & $-80 \% /+140 \%$ & $-80 \% /+140 \%$ \\
\hline Estimated range & $0.04-0.53 \mathrm{Wm}^{-2}$ & $0.04-0.50 \mathrm{Wm}^{-2}$ \\
\hline
\end{tabular}

altitudes increases the radiative effect as a result of the larger solar flux at high altitudes (Samset and Myhre, 2011). Generally, in our simulation a $10 \%$ increase in the fraction of $\mathrm{BC}$ above $5 \mathrm{~km}$ leads to a $60 \mathrm{Wm}^{-2}$ increase in AFE. The AeroCom-model overestimate of $\mathrm{BC}$ mass at high altitudes implies that their AFE is also overestimated.

Compared to the AeroCom models, our model with fast scavenging represents both near-source and remote BC concentrations better, and also simulates a higher AAOD (in better agreement with AERONET) and lower BC DRF. The smaller modeled DRF and smaller AAOD bias produce a scaled DRF which is far less than that in Bond et al. (2013) ( 0.21 vs. $0.71,70 \%$ difference) and AR5 estimates, suggesting that the direct radiative forcing from $\mathrm{BC}$ has been overestimated.

\subsection{Uncertainties}

We estimate an overall uncertainty of $-80 \% /+140 \%$ for DRE and DRF, which is summarized in detail in Table 3. There are large uncertainties associated with the AERONET AAOD observations. The uncertainty from the AERONET retrieval is estimated as the largest difference when using AOD and SSA from different AERONET versions. The $4 \%$ uncertainty associated with clear-sky observational sampling is calculated from model experiments based on GEOS-5 meteorology, and is similar to estimates of Wang et al. (2014) (3\%) and Bond et al. (2013) (1\%).

We do not estimate the uncertainties associated with detailed model processes as scaling the AAOD incorporates the bias from all of these processes. However these scale factors are based on a limited number of AERONET sites. By randomly sampling $75 \%$ of all AERONET sites to calculate scale factors in each region, we estimate this uncertainty as $-40 \% /+65 \%$. We also include an additional uncertainty associated with the AAOD over oceans. The average ratio of AERONET AAOD to modeled AAOD at island or coastal sites is 2.1 , which is not included in the scaling in Sect. 6.1. This ratio indicates that the modeled AAOD at
AERONET sites needs to be scaled up by about $100 \%$ to meet the measurements. However, in the mass concentration analysis in Sect. 4.1, our model simulation remains biased high by $\sim 50 \%$ in some oceanic areas. Thus we estimate the uncertainty in ocean AAOD to be $-50 \% /+100 \%$.

The uncertainty related to dust contributions to AAOD is taken from Bond et al. (2013). Uncertainty associated with $\mathrm{BrC}$ is estimated by assuming two extreme conditions: no $\mathrm{BrC}$ and maximum $\mathrm{BrC}$ absorption (90\% of POA from biomass burning and biofuel is assumed to be $\mathrm{BrC}$ ). These extremes result in $+40 \%$ and $-22 \%$ difference to scaled BC DRE.

Scaling DRE/DRF based on column AAOD includes the uncertainty associated with the vertical profile of BC. Zarzycki and Bond (2010) developed a column-weighting scheme and estimate that this uncertainty can be as high as $40 \%$. We estimate this uncertainty by conducting sensitivity tests by increasing/decreasing the $\mathrm{BC}$ fraction above $5 \mathrm{~km}$ by $50 \%$. This suggests a $\pm 35 \%$ uncertainty in DRE and DRF. Finally, it is unclear whether the pre-industrial DRE should be scaled when predicting DRF. In our calculations, the pre-industrial DRE is not scaled, that is, we assume that the biases are the result of emissions. If we scale the pre-industrial BC DRE, the final estimated BC DRF will be $+0.19 \mathrm{Wm}^{-2}$, equivalent to a $-10 \%$ uncertainty in DRF (but not DRE).

The total uncertainty (calculated as the root sum of squared error, assuming the uncertainties described above are independent) is estimated at $-80 \% /+140 \%$ for both DRE and DRF. Our final estimate for the range in global mean BC DRE and DRF is $0.04-0.53$ and $0.04-0.50 \mathrm{Wm}^{-2}$.

\section{Conclusions and implications}

We use the GEOS-Chem global chemical transport model integrated with online RRTMG radiation transfer model (GCRT) to investigate the mass concentrations, optical properties and radiative effect of black carbon (BC). We separate $\mathrm{BC}$ by sources and update our treatment of aging, size, and 
absorption efficiency. We also include brown carbon $(\mathrm{BrC})$ as an absorber. These modifications represent a significant advance over previous global modeling approaches.

Our model captures the magnitude of BC mass concentrations in near source regions. However, the model overestimates $\mathrm{BC}$ concentrations over the remote oceans compared to HIPPO observations, although the updated aging has improved the simulation of these low concentrations. Our simulated BC lifetime and mass load are lower than AeroCom models. Both previous studies (Koch et al., 2009; Wang et al., 2014) and our own work show that BC concentrations have been overestimated in remote areas and at high altitude and that the overestimate cannot be eliminated with simple modifications to the scavenging or aging scheme. This suggests that the $\mathrm{BC}$ atmospheric lifetime is lower than $\sim 4$ days.

Previously, nearly all models have substantially underestimated the absorption aerosol optical depth (AAOD) (Koch et al., 2009; Bond et al., 2013 and references therein) reported at ground-based AERONET network sites. Our updated optical properties for $\mathrm{BC}$ and the inclusion of brown carbon have reduced the bias by more than $50 \%$ in AAOD and almost eliminated the bias in absorption Ångström exponent (AAE) in typical urban areas. In a sensitivity simulation where we use an upper-limit estimate of absorption enhancement, we capture the magnitude of AERONET AAOD very well in typical anthropogenic emissions dominated areas (US and East Asia). The "best" model biases range from -35 to $-178 \%$ in different regions. These biases incorporate errors in both BC mass and optical properties; it is therefore not appropriate to use these to scale emissions.

After scaling our simulated AAOD to match AERONET measurements over land, we estimate that the global mean DRF of BC is $0.21(0.04-0.50) \mathrm{Wm}^{-2}$. Our estimate of the DRF is smaller than almost all the recent estimates which range from 0.19 to $0.9 \mathrm{Wm}^{-2}$ (IPCC, 2013; Myhre et al., 2013; Bond et al., 2013; Wang et al., 2014; Chung et al., 2012). This can be attributed to three factors: (1) lower BC mass concentrations in remote oceans and at high altitude, in agreement with observations; (2) updated treatment of both aging and optical properties for BC from different sources, (3) inclusion of the absorption from $\mathrm{BrC}$, which may have been incorrectly attributed to $\mathrm{BC}$ absorption in some previous studies. Although these three factors have been suggested by many studies (Cappa et al., 2012; Zhang et al., 2013; Liu et al., 2013; Wang et al., 2014; Koch et al., 2009), no study has included all of these effects in a radiative forcing estimate for BC. Additional observations of both mass and absorption efficiency for $\mathrm{BC}$ and $\mathrm{BrC}$ are needed, particularly in the Southern Hemisphere, to reduce the uncertainty on this estimate. Reducing $\mathrm{BC}$ emissions has been suggested as a policy option to mitigate climate change from greenhouse gas forcing, with a co-benefit of improving air quality (Ramanathan and Carmichael, 2008; Smith and Haigler, 2008). Our work indicates that the effectiveness of this policy may be more limited than recent work suggests.
Acknowledgements. This work was supported by the EPA-STAR program. Although the research described in this article has been funded in part by the US EPA through grant/cooperative agreement (RD-83503301), it has not been subjected to the Agency's required peer and policy review and therefore does not necessarily reflect the views of the Agency and no official endorsement should be inferred. We thank Cameron McNaughton and Yutaka Kondo for providing measurements of $\mathrm{BC}$ mass concentrations from the ARCTAS campaign.

Edited by: K. Tsigaridis

\section{References}

Adachi, K., Chung, S. H., and Buseck, P. R.: Shapes of soot aerosol particles and implications for their effects on climate, J. Geophys. Res., 115, D15206, doi:10.1029/2009JD012868, 2010.

Akagi, S. K., Craven, J. S., Taylor, J. W., McMeeking, G. R., Yokelson, R. J., Burling, I. R., Urbanski, S. P., Wold, C. E., Seinfeld, J. H., Coe, H., Alvarado, M. J., and Weise, D. R.: Evolution of trace gases and particles emitted by a chaparral fire in California, Atmos. Chem. Phys., 12, 1397-1421, doi:10.5194/acp-12-13972012, 2012.

Anenberg, S. C., Schwartz, J., Shindell, D., Amann, M., Faluvegi, G., Klimont, Z., Janssens-Maenhout, G., Pozzoli, L., Dingenen, R. V., Vignati, E., Emberson, L., Muller, N. Z., West, J. J., Williams, M., Demkine, V., Hicks, W. K., Kuylenstierna, J., Raes, F., and Ramanathan V.: Global air quality and health cobenefits of mitigating near-term climate change through methane and black carbon emission controls, Environ. Health Persp., 120, 831-839, 2012.

Arola, A., Schuster, G., Myhre, G., Kazadzis, S., Dey, S., and Tripathi, S. N.: Inferring absorbing organic carbon content from AERONET data, Atmos. Chem. Phys., 11, 215-225, doi:10.5194/acp-11-215-2011, 2011.

Bahadur, R., Praveen, P. S., Xu, Y., and Ramanathan, V.: Solar absorption by elemental and brown carbon determined from spectral observations, P. Natl. Acad. Sci. USA, 109, 43, 1736617371, doi:10.1073/pnas.1205910109, 2012.

Barnard, J. C., Volkamer, R., and Kassianov, E. I.: Estimation of the mass absorption cross section of the organic carbon component of aerosols in the Mexico City Metropolitan Area, Atmos. Chem. Phys., 8, 6665-6679, doi:10.5194/acp-8-6665-2008, 2008.

Bey, I., Jacob, D. J., Yantosca, R. M., Logan, J. A., Field, B., Fiore, A. M., Li, Q., Liu, H., Mickley, L. J., and Schultz, M.: Global modeling of tropospheric chemistry with assimilated meteorology: Model description and evaluation, J. Geophys. Res., 106, 23073-23095, 2001.

Bond, T. C. and Bergstrom, R. W.: Light absorption by carbonaceous particles: an investigative review, Aerosol Sci. Tech., 40, 27-67, doi:10.1080/02786820500421521, 2006.

Bond, T. C., Habib, G., and Bergstrom, R. W.: Limitations in the enhancement of visible light absorption due to mixing state, J Geophys. Res., 111, D20211, doi:10.1029/2006JD007315, 2006.

Bond, T. C., Bhardwaj, E., Dong, R., Jogani, R., Jung, S. K., Roden, C., Streets, D. G., and Trautmann, N. M.: Historical emissions of black and organic carbon aerosol from energy-related combustion, 1850-2000, Global Biogeochem. Cy., 21, GB2018, doi:10.1029/2006GB002840, 2007. 
Bond, T. C., Doherty, S., Fahey, D., Forster, P., Berntsen, T., DeAngelo, B., Flanner, M., Ghan, S., Kärcher, B., and Koch, D.: Bounding the role of black carbon in the climate system: A scientific assessment, J. Geophys. Res.-Atmos., 118, 5380-5552, doi:10.1002/jgrd.50171, 2013.

Bueno, P. A., Havey, D. K., Mulholland, G. W., Hodges, J. T., Gillis, K. A., Dickerson, R., and Zachariah, M. R.: Photoacoustic Measurements of Amplification of the Absorption Cross Section for Coated Soot Aerosols, Aerosol Sci. Tech., 45, 10, 1217-1230, 2011.

Cappa, C. D., Onasch, T. B., Massoli, P., Worsnop, D. R., Bates, T. S., Cross, E. S., Davidovits, P., Hakala, J., Hayden, K. L., Jobson, B. T., Kolesar, K. R., Lack, D. A., Lerner, B. M., Li, S.-M., Mellon, D., Nuaaman, I., Olfert, J. S., Petäjä, T., Quinn, P. K., Song, C., Subramanian, R., Williams, E. J., and Zaveri, R. A.: Radiative Absorption Enhancements Due to the Mixing State of Atmospheric Black Carbon, Science, 337, 1078-1081, doi:10.1126/science.1223447, 2012.

Chakrabarty, R. K., Moosmüller, H., Chen, L.-W. A., Lewis, K., Arnott, W. P., Mazzoleni, C., Dubey, M. K., Wold, C. E., Hao, W. M., and Kreidenweis, S. M.: Brown carbon in tar balls from smoldering biomass combustion, Atmos. Chem. Phys., 10, 63636370, doi:10.5194/acp-10-6363-2010, 2010.

Chen, Y. and Bond, T. C.: Light absorption by organic carbon from wood combustion, Atmos. Chem. Phys., 10, 1773-1787, doi:10.5194/acp-10-1773-2010, 2010.

Chin, M., Ginoux, P., Kinne, S., Torres, O., Holben, B., Duncan, B. N., Martin, R. V., Logan, J. A., Higurashi, A., and Nakajima, T.: Tropospheric aerosol optical thickness from the GOCART model and comparisons with satellite and sunphotometer measurements, J. Atmos. Sci., 59, 461-483, 2002.

Cooke, W. F., Liousse, C., Cachier, H., and Feichter, J.: Construction of a $1 \times 1$ fossil fuel emission data set for carbonaceous aerosol and implementation and radiative impact in the ECHAM4 model, J. Geophys. Res., 104, 22137-22162, 1999.

Chung, C. E., Ramanathan, V., and Decremer, D.: Observationally constrained estimates of carbonaceous aerosol radiative forcing, P. Natl. Acad. Sci. USA, 109, 11624-11629, doi:10.1073/pnas.1203707109, 2012.

Chung, S. H. and Seinfeld, J. H.: Global distribution and climate forcing of carbonaceous aerosols, J. Geophys. Res.-Atmos., 107, 4407, doi:10.1029/2001JD001397, 2002.

Clarke, A. D., Shinozuka, Y., Kapustin, V. N., Howell, S., Huebert, B., Doherty, S., Anderson, T., Covert, D., Anderson, J., Hua, X., Moore II, K. G., McNaughton, R., Carmichael, G., and Weber, R.: Size distributions and mixtures of dust and black carbon aerosol in Asian outflow: physiochemistry and optical properties, J. Geophys. Res., 109, D15S09, doi:10.1029/2003JD004378, 2004.

Cross, E. S., Onasch, T. B., Ahern, A., Wrobel, W., Slowik, J. G., Olfert, J., Lack, D. A., Massoli, P., Cappa, C. D., Schwarz, J. P., Spackman, J. R., Fahey, D. W., Sedlacek, A., Trimborn, A., Jayne, J. T., Freedman, A., Williams, L. R., Ng, N. L., Mazzoleni, C., Dubey, M., Brem, B., Kok, G., Subramanian, R., Freitag, S., Clarke, A., Thornhill, D., Marr, L. C., Kolb, C. E., Worsnop, D. R., and Davidovits, P.: Soot Particle Studies - Instrument InterComparison - Project Overview, Aerosol Sci. Tech., 44, 592$611,2010$.
Dachs, J. and Eisenreich, S. J.: Adsorption onto aerosol soot carbon dominates gas-particle partitioning of polycyclic aromatic hydrocarbons, Environ. Sci. Technol., 34, 3690-3697, doi:10.1021/es991201+, 2000.

Dentener, F., Kinne, S., Bond, T., Boucher, O., Cofala, J., Generoso, S., Ginoux, P., Gong, S., Hoelzemann, J. J., Ito, A., Marelli, L., Penner, J. E., Putaud, J.-P., Textor, C., Schulz, M., van der Werf, G. R., and Wilson, J.: Emissions of primary aerosol and precursor gases in the years 2000 and 1750 prescribed data-sets for AeroCom, Atmos. Chem. Phys., 6, 4321-4344, doi:10.5194/acp-64321-2006, 2006.

Desyaterik, Y., Sun, Y., Shen, X., Lee, T., Wang, X., Wang, T., and Collett Jr., J. L.: Speciation of "brown" carbon in cloud water impacted by agricultural biomass burning in eastern China, J. Geophys. Res.-Atmos., 118, 7389-7399, doi:10.1002/jgrd.50561, 2013.

Diehl, T., Heil, A., Chin, M., Pan, X., Streets, D., Schultz, M., and Kinne, S.: Anthropogenic, biomass burning, and volcanic emissions of black carbon, organic carbon, and $\mathrm{SO}_{2}$ from 1980 to 2010 for hindcast model experiments, Atmos. Chem. Phys. Discuss., 12, 24895-24954, doi:10.5194/acpd-12-24895-2012, 2012.

Drury, E. E., Jacob, D. J., Spurr, R. J. D.,Wang, J., Shinozuka, Y., Anderson, B. E., Clarke, A. D., Dibb, J., McNaughton, C., andWeber, R. J.: Synthesis of satellite (MODIS), aircraft (ICARTT), and surface (IMPROVE, EPA-AQS, AERONET) aerosol observations over eastern North America to improve MODIS aerosol retrievals and constrain aerosol concentrations and sources, J. Geophys. Res.-Atmos., 115, D14204, doi:10.1029/2009JD012629, 2010.

Dubovik, O. and King, M. D.: A flexible inversion algorithm for retrieval of aerosol optical properties from Sun and sky radiance measurements, J. Geophys. Res., 105, 20673-20696, 2000.

Dubovik, O., Holben, B., Eck, T. F., Smirnov, A., Kaufman, Y. J., King, M. D., Tanre, D., and Slutsker, I.: Variability of absorption and optical properties of key aerosol types observed in worldwide locations, J. Atmos. Sci., 59, 590-608, 2002.

Fairlie, T. D., Jacob, D. J., and Park, R. J.: The impact of transpacific transport of mineral dust in the United States, Atmos. Environ., 41, 1251-1266, 2007.

Feng, J.: A 3-mode parameterization of below-cloud scavenging of aerosols for use in 625 atmospheric dispersion models, Atmos. Environ., 41, 6808-6822, doi:10.1016/j.atmosenv.2007.04.046, 2007.

Feng, Y., Ramanathan, V., and Kotamarthi, V. R.: Brown carbon: a significant atmospheric absorber of solar radiation?, Atmos. Chem. Phys., 13, 8607-8621, doi:10.5194/acp-13-8607-2013, 2013.

Flanner, M. G., Zender, C. S., Randerson, J. T., and Rasch, P. J.: Present-day climate forcing and response from black carbon in snow, J. Geophys. Res., 112, D11202, doi:10.1029/2006JD008003, 2007.

Friedman, B., Herich, H., Kammermann, L., Gross, D. S., Arneth, A., Holst, T., and Cziczo, D. J.: Subarctic atmospheric aerosol composition: 1. Ambient aerosol characterization, J. Geophys. Res., 114, D13203, doi:10.1029/2009JD011772, 2009.

Friedman, B., Kulkarni, G., Beranek, J., Zelenyuk, A., Thornton, J. A., and Cziczo, D. J.: Ice nucleation and droplet formation by 
bare and coated soot particles, J. Geophys. Res., 116, D17203, doi:10.1029/2011JD015999, 2011.

Fuller, K. A., Malm, W. C., and Kreidenweis, S. M.: Effects of mixing on extinction by carbonaceous particles, J. Geophys. Res., 104, 15941-15954, doi:10.1029/1998JD100069, 1999.

Heald, C. L., Ridley, D. A., Kroll, J. H., Barrett, S. R. H., CadyPereira, K. E., Alvarado, M. J., and Holmes, C. D.: Contrasting the direct radiative effect and direct radiative forcing of aerosols, Atmos. Chem. Phys., 14, 5513-5527, doi:10.5194/acp-14-55132014, 2014

Hecobian, A., Zhang, X., Zheng, M., Frank, N., Edgerton, E. S., and Weber, R. J.: Water-Soluble Organic Aerosol material and the light-absorption characteristics of aqueous extracts measured over the Southeastern United States, Atmos. Chem. Phys., 10, 5965-5977, doi:10.5194/acp-10-5965-2010, 2010.

Henze, D. K. and Seinfeld, J. H.: Global secondary organic aerosol from isoprene oxidation, Geophys. Res. Lett., 33, L09812, doi:10.1029/2006GL025976, 2006.

Henze, D. K., Seinfeld, J. H., Ng, N. L., Kroll, J. H., Fu, T.-M., Jacob, D. J., and Heald, C. L.: Global modeling of secondary organic aerosol formation from aromatic hydrocarbons: highvs. low-yield pathways, Atmos. Chem. Phys., 8, 2405-2420, doi:10.5194/acp-8-2405-2008, 2008.

Holben, B. N., Tanre, D., Smirnov, A., Eck, T. F., Slutsker, I., Abuhassan, N., Newcomb, W. W., Schafer, J. S., Chatenet, B., Lavenu, F., Kaufman, Y. J., Castle, J. V., Setzer, A., Markham, B., Clark, D., Frouin, R., Halthore, R., Karneli, A., O’Neill, N. T., Pietras, C., Pinker, R. T., Voss, K., and Zibordi, G.: An emerging ground-based aerosol climatology: aerosol optical depth from AERONET, J. Geophys. Res., 106, 12067-12097, doi:10.1029/2001JD900014, 2001.

Iacono, M. J., Delamere, J. S., Mlawer, E. J., Shephard, M. W., Clough, S. A., and Collins, W. D.: Radiative forcing by long-lived greenhouse gases: calculations with the AER radiative transfer models, J. Geophys. Res.-Atmos., 113, D13103, doi:10.1029/2008jd009944, 2008.

IPCC: Climate Change 2013: The Physical Science Basis, Cambridge University Press, Cambridge, United Kingdom and New York, NY, USA, 2013.

Jacob, D. J., Crawford, J. H., Maring, H., Clarke, A. D., Dibb, J. E., Emmons, L. K., Ferrare, R. A., Hostetler, C. A., Russell, P. B., Singh, H. B., Thompson, A. M., Shaw, G. E., McCauley, E., Pederson, J. R., and Fisher, J. A.: The Arctic Research of the Composition of the Troposphere from Aircraft and Satellites (ARCTAS) mission: design, execution, and first results, Atmos. Chem. Phys., 10, 5191-5212, doi:10.5194/acp-10-5191-2010, 2010.

Jacobson, M. Z.: A physically-based treatment of elemental carbon optics: Implications for global direct forcing of aerosols, Geophys. Res. Lett., 27, 217-220, doi:10.1029/1999GL010968, 2000

Jacobson, M. Z.: Strong radiative heating due to the mixing state of black carbon in atmospheric aerosols, Nature, 409, 695-697, 2001

Jacobson, M. Z.: Investigating cloud absorption effects: Global absorption properties of black carbon, tar balls, and soil dust in clouds and aerosols, J. Geophys. Res., 117, D06205, doi:10.1029/2011JD017218, 2012.

Jaeglé, L., Quinn, P. K., Bates, T. S., Alexander, B., and Lin, J.-T.: Global distribution of sea salt aerosols: new constraints from in situ and remote sensing observations, Atmos. Chem. Phys., 11, 3137-3157, doi:10.5194/acp-11-3137-2011, 2011.

Jaoui, M., Edney, E. O., Kleindienst, T. E., Lewandowski, M., Offenberg, J. H., Surratt, J. D., and Seinfeld, J. H.: Formation of secondary organic aerosol from irradiated $\alpha$-pinene/toluene/ $\mathrm{NO}_{x}$ mixtures and the effect of isoprene and sulfur dioxide, J. Geophys. Res., 113, D09303, doi:10.1029/2007JD009426, 2008.

Kahnert, M.: On the discrepancy between modeled and measured mass absorption cross sections of light absorbing carbon aerosols, Aerosol Sci. Tech., 44, 453-460, doi:10.1080/02786821003733834, 2010.

Khalizov, A. F., Zhang, R., Zhang, D., Xue, H., Pagels, J., and McMurry, P. H.: Formation of highly hygroscopic soot aerosols upon internal mixing with sulfuric acid vapor, J. Geophys. Res., 114, D05208, doi:10.1029/2008JD010595, 2009.

Kirchstetter, T. W., Novakov, T., and Hobbs, P. V.: Evidence that the spectral dependence of light absorption by aerosols is affected by organic carbon, J. Geophys. Res., 109, D21208, doi:10.1029/2004JD004999, 2004.

Knox, A., Evans, G. J., Brook, J. R., Yao, X., Jeong, C. H., Godri, K. J., Sabaliauskas, K., and Slowik, J. G.: Mass absorption cross-section of ambient black carbon aerosol in relation to chemical age, Aerosol Sci. Tech., 43, 522-532, doi:10.1080/02786820902777207, 2009.

Koch, D.: Transport and direct radiative forcing of carbonaceous and sulfate aerosols in the GISS GCM, J. Geophys. Res., 106 , 20311-20332, doi:10.1029/2001JD900038, 2001.

Koch, D., Schulz, M., Kinne, S., McNaughton, C., Spackman, J. R., Balkanski, Y., Bauer, S., Berntsen, T., Bond, T. C., Boucher, O., Chin, M., Clarke, A., De Luca, N., Dentener, F., Diehl, T., Dubovik, O., Easter, R., Fahey, D. W., Feichter, J., Fillmore, D., Freitag, S., Ghan, S., Ginoux, P., Gong, S., Horowitz, L., Iversen, T., Kirkevåg, A., Klimont, Z., Kondo, Y., Krol, M., Liu, X., Miller, R., Montanaro, V., Moteki, N., Myhre, G., Penner, J. E., Perlwitz, J., Pitari, G., Reddy, S., Sahu, L., Sakamoto, H., Schuster, G., Schwarz, J. P., Seland, Ø., Stier, P., Takegawa, N., Takemura, T., Textor, C., van Aardenne, J. A., and Zhao, Y.: Evaluation of black carbon estimations in global aerosol models, Atmos. Chem. Phys., 9, 9001-9026, doi:10.5194/acp-9-9001-2009, 2009.

Kopke, P., Hess, M., Schult, I., and Shettle, E. P.: Global Aerosol Data Set, Max Planck Inst. für Meteorol., Hamburg, Germany, 1997.

Kondo, Y., Oshima, N., Kajino, M., Mikami, R., Moteki, N., Takegawa, N., Verma, R. L., Kajii, Y., Kato, S., and Takami, A.: Emissions of black carbon in East Asia estimated from observations at a remote site in the East China Sea, J. Geophys. Res., 116, D16201, doi:10.1029/2011JD015637, 2011a.

Kondo, Y., Matsui, H., Moteki, N., Sahu, L., Takegawa, N., Kajino, M., Zhao, Y., Cubison, M. J., Jimenez, J. L., Vay, S., Diskin, G. S., Anderson, B., Wisthaler, A., Mikoviny, T., Fuelberg, H. E., Blake, D. R., Huey, G., Weinheimer, A. J., Knapp, D. J., and Brune, W. H.: Emissions of black carbon, organic, and inorganic aerosols from biomass burning in North America and Asia in 2008, J. Geophys. Res., 116, D08204, doi:10.1029/2010JD015152, 2011b.

Lacis, A. A. and Oinas, V.: A description of the correlated kappadistribution method for modeling non-gray gaseous absorption, thermal emission, and multiple-scattering in vertically inhomo- 
geneous atmosphere, J. Geophys. Res.-Atmos., 96, 9027-9063, doi:10.1029/90jd01945, 1991.

Lack, D. A., Langridge, J. M., Bahreini, R., Cappa, C. D., Middlebrook, A. M., and Schwarz, J. P.: Brown carbon and internal mixing in biomass burning particles, P. Natl. Acad. Sci. USA, 109, 14802-14807, doi:10.1073/pnas.1206575109, 2012.

Lambe, A. T., Cappa, C. D., Massoli, P., Onasch, T. B., Forestieri, S. D., Martin, A. T., Cummings, M. J., Croasdale, D. R., Brune, W. H., Worsnop, D. R., and Davidovits, P.: Relationship between oxidation level and optical properties of secondary organic aerosol, Environ. Sci. Technol., 47, 6349-6357, 2013.

Leibensperger, E. M., Mickley, L. J., Jacob, D. J., Chen, W.-T., Seinfeld, J. H., Nenes, A., Adams, P. J., Streets, D. G., Kumar, N., and Rind, D.: Climatic effects of 1950-2050 changes in US anthropogenic aerosols - Part 1: Aerosol trends and radiative forcing, Atmos. Chem. Phys., 12, 3333-3348, doi:10.5194/acp-12-33332012, 2012.

Lewis, K. A., Arnott, W. P., Moosmüller, H., Chakrabarty, R. K., Carrico, C. M., Kreidenweis, S. M., Day, D. E., Malm, W. C., Laskin, A., Jimenez, J. L., Ulbrich, I. M., Huffman, J. A., Onasch, T. B., Trimborn, A., Liu, L., and Mishchenko, M. I.: Reduction in biomass burning aerosol light absorption upon humidification: roles of inorganically-induced hygroscopicity, particle collapse, and photoacoustic heat and mass transfer, Atmos. Chem. Phys., 9, 8949-8966, doi:10.5194/acp-9-8949-2009, 2009.

Li, Z., Zhao, X., Kahn, R., Mishchenko, M., Remer, L., Lee, K.-H., Wang, M., Laszlo, I., Nakajima, T., and Maring, H.: Uncertainties in satellite remote sensing of aerosols and impact on monitoring its long-term trend: a review and perspective, Ann. Geophys., 27, 2755-2770, doi:10.5194/angeo-27-2755-2009, 2009.

Lin, G., Penner, J. E., Flanner, M. G., Sillman, S., Xu, L., and Zhou, C.: Radiative forcing of organic aerosol in the atmosphere and on snow: effects of SOA and brown carbon, J. Geophys. Res.Atmos., 119, 7453-7476, doi:10.1002/2013JD021186, 2014.

Liousse, C., Guillaume, B., Grégoire, J. M., Mallet, M., Galy, C., Pont, V., Akpo, A., Bedou, M., Castéra, P., Dungall, L., Gardrat, E., Granier, C., Konaré, A., Malavelle, F., Mariscal, A., Mieville, A., Rosset, R., Serça, D., Solmon, F., Tummon, F., Assamoi, E., Yoboué, V., and Van Velthoven, P.: Updated African biomass burning emission inventories in the framework of the AMMAIDAF program, with an evaluation of combustion aerosols, Atmos. Chem. Phys., 10, 9631-9646, doi:10.5194/acp-10-96312010, 2010.

Liu, J., Fan, S., Horowitz, L. W., and Levy II, H.: Evaluation of factors controlling long-range transport of black carbon to the Arctic, J. Geophys. Res., 116, D04307, doi:10.1029/2010JD015145, 2011.

Liu, J., Bergin, M., Guo, H., King, L., Kotra, N., Edgerton, E., and Weber, R. J.: Size-resolved measurements of brown carbon in water and methanol extracts and estimates of their contribution to ambient fine-particle light absorption, Atmos. Chem. Phys., 13, 12389-12404, doi:10.5194/acp-13-12389-2013, 2013.

Liu, H. Y., Jacob, D. J., Bey, I., and Yantosca, R. M.: Constraints from $\mathrm{Pb}-210$ and $\mathrm{Be}-7$ on wet deposition and transport in a global three-dimensional chemical tracer model driven by assimilated meteorological fields, J. Geophys. Res.-Atmos., 106, 12109-12128, 2001.
Lukács, H., Gelencsér, A., Hammer, S., Puxbaum, H., Pio, C., Legrand, M., Kasper-Giebl, A., Handler, M., Limbeck, A., Simpson, D., and Preunkert, S.: Seasonal trends and possible sources of brown carbon based on 2-year aerosol measurements at six sites in Europe, J. Geophys. Res., 112, D23S18, doi:10.1029/2006JD008151, 2007.

Martin, R. V., Jacob, D. J., Yantosca, R. M., Chin, M., and Ginoux, P.: Global and regional decreases in tropospheric oxidants from photochemical effects of aerosols, J. Geophys. Res., 108, 4097, doi:10.1029/2002JD002622, 2003.

McMeeking, G. R., Hamburger, T., Liu, D., Flynn, M., Morgan, W. T., Northway, M., Highwood, E. J., Krejci, R., Allan, J. D., Minikin, A., and Coe, H.: Black carbon measurements in the boundary layer over western and northern Europe, Atmos. Chem. Phys., 10, 9393-9414, doi:10.5194/acp-10-9393-2010, 2010.

Mishchenko, M. I., Dlugach, J. M., Yanovitskij, E. G., and Zakharova, N. T.: Bidirectional reflectance of flat optically thick particulate layers: an efficient radiative transfer solution and applications to snow and soil surfaces, J. Quant. Spectrosc. Ra., 63, 409-432, 1999.

Moffet, R. C. and Prather, K. A.: In-situ measurements of the mixing state and optical properties of soot with implications for radiative forcing estimates, P. Natl. Acad. Sci. USA, 106, 11872 11877, doi:10.1073/pnas.0900040106, 2009.

Moteki, N., Kondo, Y., Miyazaki, Y., Takegawa, N., Komazaki, Y., Kurata, G., Shirai, T., Blake, D. R., Miyakawa, T., and Koike, M.: Evolution of mixing state of black carbon particles: Aircraft measurements over the western Pacific in March 2004, Geophys. Res. Lett., 34, L11803, doi:10.1029/2006GL028943, 2007.

Myhre, G., Samset, B. H., Schulz, M., Balkanski, Y., Bauer, S., Berntsen, T. K., Bian, H., Bellouin, N., Chin, M., Diehl, T., Easter, R. C., Feichter, J., Ghan, S. J., Hauglustaine, D., Iversen, T., Kinne, S., Kirkevåg, A., Lamarque, J.-F., Lin, G., Liu, X., Lund, M. T., Luo, G., Ma, X., van Noije, T., Penner, J. E., Rasch, P. J., Ruiz, A., Seland, Ø., Skeie, R. B., Stier, P., Takemura, T., Tsigaridis, K., Wang, P., Wang, Z., Xu, L., Yu, H., Yu, F., Yoon, J.-H., Zhang, K., Zhang, H., and Zhou, C.: Radiative forcing of the direct aerosol effect from AeroCom Phase II simulations, Atmos. Chem. Phys., 13, 1853-1877, doi:10.5194/acp-13-18532013, 2013.

Nakayama, T., Sato, K., Matsumi, Y., Imamura, T., Yamazaki, A., and Uchiyama, A.: Wavelength and $\mathrm{NO}_{\mathrm{x}}$ dependent complex refractive index of SOAs generated from the photooxidation of toluene, Atmos. Chem. Phys., 13, 531-545, doi:10.5194/acp-13531-2013, 2013.

Park, R. J., Jacob, D. J., Chin, M., and Martin, R. V.: Sources of carbonaceous aerosols over the United States and implications for natural visibility, J. Geophys. Res., 108, 4355, doi:10.1029/2002JD003190, 2003.

Park, R. J., Kim, M. J., Jeong, J. I., Youn, D., and Kim, S.: A contribution of brown carbon aerosol to the aerosol light absorption and its radiative forcing in East Asia, Atmos. Environ., 44, 1414 1421, 2010.

Ramanathan, V. and Carmichael, G.: Global and regional climate changes due to black carbon, Nat. Geosci., 1, 221-227, doi:10.1038/ngeo156, 2008.

Rastigejev, Y., Park, R., Brenner, M. P., and Jacob, D. J.: Resolving intercontinental pollution plumes in global mod- 
els of atmospheric transport, J. Geophys. Res., 115, D02302, doi:10.1029/2009JD012568, 2010.

Ridley, D. A., Heald, C. L., and Ford, B. J.: North African dust export and impacts: an integrated satellite and model perspective, J. Geophys. Res.-Atmos., 117, D02202, doi:10.1029/2011JD016794, 2012.

Russell, P. B., Bergstrom, R. W., Shinozuka, Y., Clarke, A. D., DeCarlo, P. F., Jimenez, J. L., Livingston, J. M., Redemann, J., Dubovik, O., and Strawa, A.: Absorption Angstrom Exponent in AERONET and related data as an indicator of aerosol composition, Atmos. Chem. Phys., 10, 1155-1169, doi:10.5194/acp-101155-2010, 2010.

Saleh, R., Hennigan, C. J., McMeeking, G. R., Chuang, W. K., Robinson, E. S., Coe, H., Donahue, N. M., and Robinson, A. L.: Absorptivity of brown carbon in fresh and photo-chemically aged biomass-burning emissions, Atmos. Chem. Phys., 13, 76837693, doi:10.5194/acp-13-7683-2013, 2013.

Samset, B. H. and Myhre, G.: Vertical dependence of black carbon, sulphate and biomass burning aerosol radiative forcing, Geophys. Res. Lett., 38, L24802, doi:10.1029/2011GL049697, 2011.

Schnaiter, M., Linke, C., Möhler, O., Naumann, K.-H., Saathoff, H., Wagner, R., Schurath, U., and Wehner, B.: Absorption amplification of black carbon internally mixed with secondary organic aerosol, J. Geophys. Res., 110, D19204, doi:10.1029/2005JD006046, 2005.

Schulz, M., Textor, C., Kinne, S., Balkanski, Y., Bauer, S., Berntsen, T., Berglen, T., Boucher, O., Dentener, F., Guibert, S., Isaksen, I. S. A., Iversen, T., Koch, D., Kirkevåg, A., Liu, X., Montanaro, V., Myhre, G., Penner, J. E., Pitari, G., Reddy, S., Seland, $\varnothing$., Stier, P., and Takemura, T.: Radiative forcing by aerosols as derived from the AeroCom present-day and pre-industrial simulations, Atmos. Chem. Phys., 6, 5225-5246, doi:10.5194/acp-65225-2006, 2006.

Schwarz, J. P., Spackman, J. R., Fahey, D. W., Gao, R. S., Lohmann, U., Stier, P., Watts, L. A., Thomson, D. S., Lack, D. A., Pfister, L., Mahoney, M. J., Baumgardner, D., Wilson, J. C., and Reeves, J. M.: Coatings and their enhancement of black carbon light absorption in the tropical atmosphere, J. Geophys. Res., 113, D03203, doi:10.1029/2007JD009042, 2008a.

Schwarz, J. P., Gao, R. S., Spackman, J. R., Watts, L. A., Thomson, D. S., Fahey, D. W., Ryerson, T. B., Peischl, J., Holloway, J. S., Trainer, M., Frost, G. J., Baynard, T., Lack, D. A., de Gouw, J. A., Warneke, C., and Del Negro, L. A.: Measurement of the mixing state, mass, and optical size of individual black carbon particles in urban and biomass burning emissions, Geophys. Res. Lett., 35, L13810, doi:10.1029/2008GL033968, 2008b.

Schwarz, J. P., Spackman, J. R., Gao, R. S., Watts, L. A., Stier, P., Schulz, M., Davis, S. M., Wofsy, S. C., and Fahey, D. W.: Global-scale black carbon profiles observed in the remote atmosphere and compared to models, Geophys. Res. Lett., 37, L18812, doi:10.1029/2010GL044372, 2010.

Schwarz, J. P., Samset, B. H., Perring, A. E., Spackman, J. R., Gao, R. S., Stier, P., Schulz, M., Moore, F. L., Ray, E. A., and Fahey, D. W.: Global-scale seasonally resolved black carbon vertical profiles over the Pacific, Geophys. Res. Lett., 40, 5542-5547, doi:10.1002/2013GL057775, 2013.

Seinfeld, J. H. and Pandis, S. N.: Atmospheric Chemistry and Physics, From Air Pollution to Climate Change, 2nd Edn., John Wiley, Hoboken, N. J., 266-267, 2006.
Shamjad, P. M., Tripathi, S. N., Aggarwal, S. G., Mishra, S. K., Joshi, M., Khan, A., Sapra, B. K., and Ram, K.: Comparison of experimental and modeled absorption enhancement by black carbon (BC) cored poly disperse aerosols under hygroscopic conditions, Environ. Sci. Technol., 46, 8082-8089, 2012.

Shiraiwa, M., Kondo, Y., Iwamoto, T., and Kita, K.: Amplification of Light Absorption of Black Carbon by Organic Coating, Aerosol Sci. Tech., 44, 46-54, 2010.

Smith, K. R. and Haigler, E.: Co-Benefits of Climate Mitigation and Health Protection in Energy Systems: Scoping Methods. Annu. Rev. Publ. Health, 29, 11-25, 2008.

Song, C., Gyawali, M., Zaveri, R. A., Shilling, J. E., and Arnott, W. P.: Light absorption by secondary organic aerosol from $\alpha$-pinene: Effects of oxidants, seed aerosol acidity, and relative humidity, J. Geophys. Res.-Atmos., 118, 11741-11749, doi:10.1002/jgrd.50767, 2013.

Stier, P., Seinfeld, J. H., Kinne, S., Feichter, J., and Boucher, O.: Impact of nonabsorbing anthropogenic aerosols on clearsky atmospheric absorption, J. Geophys. Res., 111, D18201, doi:10.1029/2006JD007147, 2006.

Updyke, K. M., Nguyen, T. B., and Nizkorodov, S. A.: Formation of brown carbon via reactions of ammonia with secondary organic aerosols from biogenic and anthropogenic precursors, Atmos. Environ., 63, 22-31, 2012.

van der Werf, G. R., Randerson, J. T., Giglio, L., Collatz, G. J., Mu, M., Kasibhatla, P. S., Morton, D. C., DeFries, R. S., Jin, Y., and van Leeuwen, T. T.: Global fire emissions and the contribution of deforestation, savanna, forest, agricultural, and peat fires (19972009), Atmos. Chem. Phys., 10, 11707-11735, doi:10.5194/acp10-11707-2010, 2010.

Vignati, E., Karl, M., Krol, M., Wilson, J., Stier, P., and Cavalli, F.: Sources of uncertainties in modelling black carbon at the global scale, Atmos. Chem. Phys., 10, 2595-2611, doi:10.5194/acp-102595-2010, 2010.

Wang, Q., Jacob, D. J., Fisher, J. A., Mao, J., Leibensperger, E. M., Carouge, C. C., Le Sager, P., Kondo, Y., Jimenez, J. L., Cubison, M. J., and Doherty, S. J.: Sources of carbonaceous aerosols and deposited black carbon in the Arctic in winter-spring: implications for radiative forcing, Atmos. Chem. Phys., 11, 1245312473, doi:10.5194/acp-11-12453-2011, 2011.

Wang, Q., Jacob, D. J., Spackman, J. R., Perring, A. E., Schwarz, J. P., Moteki, N., Marais, E. A., Ge, C., Wang, J., and Barrett, S. R. H.: Global budget and radiative forcing of black carbon aerosol: constraints from pole-to-pole (HIPPO) observations across the Pacific, J. Geophys. Res.-Atmos., 119, 195-206, doi:10.1002/2013JD020824, 2014.

Wang, X., Wang, Y., Hao, J., Kondo, Y., Irwin, M., Munger, J. W., and Zhao, Y.: Top-down estimate of China's black carbon emissions using surface observations: sensitivity to observation representativeness and transport model error, J. Geophys. Res.Atmos., 118, 5781-5795, doi:10.1002/jgrd.50397, 2013.

Wiedinmyer, C., Akagi, S. K., Yokelson, R. J., Emmons, L. K., AlSaadi, J. A., Orlando, J. J., and Soja, A. J.: The Fire INventory from NCAR (FINN): a high resolution global model to estimate the emissions from open burning, Geosci. Model Dev., 4, 625641, doi:10.5194/gmd-4-625-2011, 2011.

Yang, M., Howell, S. G., Zhuang, J., and Huebert, B. J.: Attribution of aerosol light absorption to black carbon, brown carbon, and dust in China - interpretations of atmospheric measure- 
ments during EAST-AIRE, Atmos. Chem. Phys., 9, 2035-2050, doi:10.5194/acp-9-2035-2009, 2009.

Zarzycki, C. M. and Bond, T. C.: How much can the vertical distribution of black carbon affect its global direct radiative forcing?, Geophys. Res. Lett., 37, L20807, doi:10.1029/2010GL044555, 2010.

Zhang, Q., Streets, D. G., Carmichael, G. R., He, K. B., Huo, H., Kannari, A., Klimont, Z., Park, I. S., Reddy, S., Fu, J. S., Chen, D., Duan, L., Lei, Y., Wang, L. T., and Yao, Z. L.: Asian emissions in 2006 for the NASA INTEX-B mission, Atmos. Chem. Phys., 9, 5131-5153, doi:10.5194/acp-9-5131-2009, 2009.

Zhang, R., Khalizov, A. F., Pagels, J., Zhang, D., Xue, H., and McMurry, P. H.: Variability in morphology, hygroscopicity, and optical properties of soot aerosols during atmospheric processing, P. Natl. Acad. Sci. USA, 105, 10291-10296, doi:10.1073/pnas.0804860105, 2008.
Zhang, L. M., Gong, S. L., Padro, J., and Barrie, L.: A sizesegregated particle dry deposition scheme for an atmospheric aerosol module, Atmos. Environ., 35, 549-560, 2001.

Zhang, X. L., Lin, Y. H., Surratt, J. D., and Weber, R. J.: Sources, Composition and Absorption Ångström Exponent of Light absorbing Organic Components in Aerosol Extracts from the Los Angeles Basin, Environ. Sci. Technol., 47, 3685-3693, 2013.

Zhang, X. Y., Wang, Y. Q., Zhang, X. C., Guo, W., Gong, S. L., Zhao, P., and Jin, J. L.: Carbonaceous aerosol composition over various regions of China during 2006, J. Geophys. Res., 113, D14111, doi:10.1029/2007JD009525, 2008. 